\title{
1 Slab melting and magma formation beneath the southern Cascade Arc
}

3 Walowski, K.J. ${ }^{1}{ }^{2 *}{ }^{*}$, Wallace, P.J. ${ }^{1}$, Clynne, M.A. ${ }^{3}$, Rasmussen, D.J. ${ }^{4}$, Weis, D. ${ }^{5}$

$5 \quad{ }^{1}$ University of Oregon, Department of Geological Sciences, Eugene, OR, USA

62 University of Edinburgh, School of Geosciences, Grant Institute, Edinburgh, UK

$7 \quad{ }^{3}$ United States Geological Survey, Volcano Science Center, Menlo Park, CA, USA

$8 \quad{ }^{4}$ Lamont Doherty Earth Observatory, Palisades, NY, USA

$9{ }^{5}$ University of British Columbia, Earth, Ocean, and Atmospheric Science Department,

10 Vancouver, BC, Canada

11

12 *Corresponding Author - Current contact information: k.walowski@ed.ac.uk

14 Keywords: Subduction zone; Volatiles; Cascades; Melt inclusions; GeocheMItry; Arc

16 Abstract

17 The processes that drive magma formation beneath the Cascade arc and

18 other warm-slab subduction zones have been debated because young oceanic crust

19 is predicted to largely dehydrate beneath the forearc during subduction. In addition,

20 geochemical variability along strike in the Cascades has led to contrasting

21 interpretations about the role of volatiles in magma generation. Here, we focus on

22 the Lassen segment of the Cascade arc, where previous work has demonstrated

23 across-arc geochemical variations related to subduction enrichment, and H-isotope 
24 data suggest that $\mathrm{H}_{2} \mathrm{O}$ in basaltic magmas is derived from the final breakdown of

25 chlorite in the mantle portion of the slab. We use naturally glassy, olivine-hosted

26 melt inclusions (MI) from the tephra deposits of eight primitive ( $\mathrm{MgO}>7 \mathrm{wt} \%)$

27 basaltic cinder cones to quantify the pre-eruptive volatile contents of mantle-

28 derived melts in this region. The melt inclusions have B concentrations and isotope

29 ratios that are similar to mid-ocean ridge basalt (MORB), suggesting extensive

30 dehydration of the downgoing plate prior to reaching sub-arc depths and little input

31 of slab-derived B into the mantle wedge. However, correlations of volatile and trace

32 element ratios $\left(\mathrm{H}_{2} \mathrm{O} / \mathrm{Ce}, \mathrm{Cl} / \mathrm{Nb}, \mathrm{Sr} / \mathrm{Nd}\right)$ in the melt inclusions demonstrate that

33 geochemical variability is the result of variable addition of a hydrous subduction

34 component to the mantle wedge. Furthermore, correlations between subduction

35 component tracers and radiogenic isotope ratios show that the subduction

36 component has less radiogenic $\mathrm{Sr}$ and $\mathrm{Pb}$ than the Lassen sub-arc mantle, which can

37 be explained by melting of subducted Gorda MORB beneath the arc. Agreement

38 between pMELTS melting models and melt inclusion volatile, major, and trace

39 element data suggests that hydrous slab melt addition to the mantle wedge can

40 produce the range in primitive compositions erupted in the Lassen region. Our

41 results provide further evidence that chlorite-derived fluids from the mantle portion

42 of the slab ( 7-9 km below the slab top) cause flux melting of the subducted oceanic

43 crust, producing hydrous slab melts that migrate into the overlying mantle, where

44 they react with peridotite to induce further melting.

46 1. Introduction 
48 Dehydration of subducted oceanic lithosphere drives arc magmatism at

49 convergent plate margins. However, the thermal structure of an individual

50 subduction zone controls the depths at which key dehydration reactions occur

51 (Schmidt and Poli, 1998; Van Keken et al., 2011). Thermal structure is commonly

52 assessed using the thermal parameter $(\phi)$, which is a function of downgoing plate

53 age, dip angle, and convergence rate (e.g., Syracuse et al., 2010). Variability in $\phi$

54 globally is predicted to cause a wide range of slab surface temperatures beneath

$55 \operatorname{arcs}\left(675-950^{\circ} \mathrm{C}\right)$, as estimated from geodynamic models (e.g., Syracuse et al., 2010)

56 and geochemical tools (e.g., Cooper et al., 2012). The results suggest a continuum of

57 subduction zones between 'cold' (Tonga, Kamchatka) and 'warm' slabs (Cascades,

58 Mexico). Fluids released from the subducting slab have been shown to become more

59 solute-rich with increased temperature (Kessel et al., 2005a; Herman and Spandler,

60 2006; Cooper et al., 2012; Ruscitto et al., 2012), and there is geochemical evidence

61 for melting of the oceanic crust beneath some warm-slab endmembers such Mexico

62 (Cai et al., 2014), the Cascades (Walowski et al., 2015), and SW Japan (Kimura et al.,

63 2014). In addition, there is widespread geochemical evidence for melting of

64 subducted sediment beneath arcs (e.g., Plank et al., 2005). However, whether the

65 oceanic crust begins to melt beneath most arcs has been debated, and a consensus is

66 emerging that the oceanic crust dehydrates and contributes fluids to the mantle

67 wedge in arcs with cold to intermediate slab temperatures (e.g., van Keken et al.,

68 2011). To understand slab recycling and magma generation, it is imperative to

69 differentiate the roles of different components in the subducted oceanic lithosphere 
70 (altered oceanic crust, sediment, serpentinized peridotite) and determine how these

71 components are transferred to the overlying mantle wedge (as fluids, melts or a

72 supercritical phase). The Cascade arc represents a global warm-slab endmember

73 due to slow, shallow subduction of young oceanic crust (6-10 Ma at the trench;

74 Wilson et al., 2002). Geodynamic models (Syracuse et al., 2010; Wada and Wang,

75 2009) and geochemical studies (Cooper et al., 2012; Ruscitto et al., 2012; Walowski

76 et al., 2015) agree that slab surface temperatures beneath the arc axis are hotter, on

77 average, than many other arcs globally. Previous work in the central Oregon

78 Cascades has suggested that the mantle wedge beneath the arc receives a reduced

79 flux of volatiles from the downgoing slab (Ruscitto et al., 2012), and $\mathrm{H}_{2} \mathrm{O}$

80 concentrations in olivine-hosted melt inclusions (MI) from both the central and

81 southern Cascades ( $\sim 3.2 \mathrm{wt} \%$; Ruscitto et al., 2010, 2011; LeVoyer et al., 2010) fall

82 slightly below the global average ( $\sim 3.9$ wt\%; Plank et al., 2013). Walowski et al.

83 (2015) found that hydrogen isotope ratios of primitive magmas from the Lassen

84 region of the southern Cascades are lighter than those for the Mariana arc. This is

85 likely the result of waning dehydration of chlorite in the mantle portion of the

86 downgoing slab ( $\sim 7-9 \mathrm{~km}$ below the slab top) after the crustal portion of the slab

87 has already dehydrated beneath the forearc. These results also provide evidence

88 that flux-melting of the oceanic crust occurs when fluids released from the slab

89 interior interact with oceanic crust that is above its wet solidus temperature (e.g.,

90 Spandler and Pirard, 2013).

91 We measured the volatile contents, major element, trace element, and B

92 isotope compositions of olivine-hosted MI and the radiogenic isotopic compositions 
93 of bulk tephra from the eruptive centers in the Lassen region studied by Walowski

94 et al. (2015). We use these data to quantify the chemical contributions from the

95 subducting oceanic lithosphere and to better understand how subduction of warm

96 oceanic crust affects the composition of mantle melts and the productivity of

97 melting in the mantle wedge. We also test the hypothesis of Walowski et al. (2015)

98 that magma production beneath the southern Cascades involves a multi-stage

99 process that includes flux melting of the subducted oceanic crust and hydrous slab

100 melt addition to the overlying mantle wedge.

101

\section{2. Geologic Setting}

103 The Lassen region is the southern terminus of the active Cascade arc

104 (Guffanti et al., 1990). Volcanism is the result of oblique subduction of the Gorda

105 micro-plate beneath the North American plate (Fig. 1; Wilson, 2002), producing

106 dominantly calc-alkaline magmas (Clynne and Muffler, 2010). Westward expansion

107 of the Basin and Range extensional province into the eastern flanks of the Cascade

108 arc, including the Hat Creek and Lake Almanor Grabens, has produced many normal

109 faults that provide pathways for mafic magmas to reach the surface (Guffanti et al.,

110 1990; Clynne and Muffler, 2010). The Quaternary volcanics in the Lassen region sit

111 above a broad platform of mafic to intermediate volcanoes and volcanic products 2-

$1124 \mathrm{~km}$ thick (Berge and Stauber, 1987), which is underlain by Sierran and Klamath

113 metamorphic/plutonic basement rocks (Berge and Stauber, 1987). Surrounding the

114 Lassen Peak dacitic dome complex (Clynne and Muffler, 2010) is a large volcanic

115 field containing over 500 cinder cones and small shield volcanoes erupted in the last 
11612 Ma (Guffanti et al., 1990). Previous work on the Quaternary mafic volcanoes has

117 identified a range in compositions from low-K tholeiitic basalts (LKT; also called

118 high-alumina olivine tholeiites, or HAOT) to calc-alkaline basalt, basaltic andesite,

119 and andesite (Clynne, 1993; Borg et al., 1997). The most primitive calc-alkaline

120 volcanic rocks show distinct across-arc geochemical variations that are interpreted

121 to result from variable enrichment of the sub-arc mantle by a subduction

122 component (Fig. 1; Borg et al., 1997, 2002). Figure 1 shows variations in both $\mathrm{Sr} / \mathrm{Nd}$

123 and ${ }^{87} \mathrm{Sr} /{ }^{86} \mathrm{Sr}$ with increasing distance from the trench. Because there is no evidence

124 for plagioclase fractionation in the primitive magmas, these ratios are robust

125 indicators of subduction enrichment (Borg et al., 1997; see Supplementary

126 Discussion and Fig. S2 for details). The pattern of variable $\mathrm{Sr} / \mathrm{Nd}$ in the forearc and

127 decreasing and consistently low values of $\mathrm{Sr} / \mathrm{Nd}$ in the back-arc has been

128 interpreted to indicate the waning addition of a subduction component with

129 distance from the trench (Borg et al., 1997). The ${ }^{87} \mathrm{Sr} /{ }^{86} \mathrm{Sr}$ ratios display an opposite

130 pattern and generally increase toward the back-arc, indicating that the subduction

131 component has a less radiogenic Sr isotope signature than the sub-arc mantle, which

132 is unusual for arc volcanoes (e.g., Turner and Langmuir, 2015). Variability in whole-

133 rock $\mathrm{Nb} / \mathrm{Zr}$ and mineral cheMItry (olivine and spinel) suggests that the Lassen sub-

134 arc mantle is heterogeneous before any slab addition (Supplementary Fig. S1;

135 Clynne, 1993; Borg et al., 1997; Walowski et al., 2015), but there is no systematic

136 variation of $\mathrm{Nb} / \mathrm{Zr}$ with distance from the trench. A full summary of geochemical

137 variations can be found in the Supplementary Materials, and a detailed review is

138 provided by Borg et al. (2002). 


\section{3. Sample Descriptions and Analytical Methods}

142 Samples were collected from the tephra deposits of Quaternary monogenetic

143 vents spanning $\sim 80 \mathrm{~km}$ from the forearc to the back-arc (Fig. 1). Vents that erupted

144 primitive basalt or basaltic andesite ( $\mathrm{MgO}>7 \mathrm{wt} \%)$ identified from bulk rock

145 analyses (Clynne, 1993; Borg et al., 1997) were targeted because they are close in

146 composition to primary mantle melts. Coarse ash was collected to minimize the

147 potential for syn-eruptive diffusive H loss (e.g., Lloyd, 2013) or crystallization of

148 melt inclusions. Loose olivine crystals (250 $\mu \mathrm{m}$ to $1 \mathrm{~mm})$ were hand-picked from

149 sieved tephra, treated in $\mathrm{HBF}_{4}$ to remove adhering glass, and examined in

150 immersion oil to locate MI. Olivine crystals hosting fully enclosed, glassy MI were

151 mounted in acetone-soluble resin on glass slides and prepared as doubly polished

152 wafers. $\mathrm{H}_{2} \mathrm{O}$ and $\mathrm{CO}_{2}$ concentrations of the MI were measured at the University of

153 Oregon using a Thermo-Nicolet Nexus 670 FTIR spectrometer interfaced with a

154 Continuum IR microscope. Concentrations were calculated from IR peak

155 absorbances using the Beer-Lambert law and compositionally appropriate

156 absorption coefficients (see Johnson et al., 2008). MI and host olivine were analyzed

157 for major elements (plus S and Cl for inclusions) on the Cameca SX-100 electron

158 microprobe at the University of Oregon (see Ruscitto et al., 2010, for details). MI

159 were subsequently analyzed for a suite of trace elements on the Photon Machines

160 Analyte G2 135 nm ArF “fast”Excimer Laser system at Oregon State University,

161 using $50 \mu \mathrm{m}$ spot size with a $5 \mathrm{~Hz}$ pulse rate. Measured trace element concentrations 
162 were determined by reference to GSE-1G glass as a calibration standard and using

163 43Ca as an internal standard (see Loewen and Kent, 2012). BHVO-2G, BCR-2G, and

164 GSD-1G glasses were also analyzed to monitor accuracy and precision, and the

165 analyzed values were within $10 \%$ of accepted values (see Supplementary Table S5).

166 A subset of the MI that were analyzed for $\mathrm{H}$ isotopes and trace elements by

167 Walowski et al. (2015) were also analyzed for B isotope ratios using the Cameca IMS

1681280 at Woods Hole Oceanographic Institution, with $0^{-}$primary beam, $30 \mathrm{nA}$

169 primary current, 10,000 V secondary voltage, and a $20 \mu \mathrm{m}$ spot size. More detailed

170 methods are described in Marschall and Monteleone (2014) and Supplementary

171 Table S3. Some of the MI were too small to allow a new SIMS spot adjacent to an

172 existing NanoSIMS spot (20x20 rastered area, $\sim 5 \mu \mathrm{m}$ deep). In these cases, the SIMS

173 spot was placed within the pre-existing NanoSIMS spot. Tests comparing

174 measurements within pre-existing spots to those on a clean surface from a single MI

175 revealed no systematic differences.

176 The $\mathrm{Sr}, \mathrm{Nd}, \mathrm{Hf}$, and $\mathrm{Pb}$ isotope ratios of bulk tephra samples were measured

177 at the Pacific Centre for Isotopic and Geochemical Research at the University of

178 British Columbia. $\mathrm{Pb}, \mathrm{Nd}$, and Hf isotope ratios were measured by MC-ICP-MS (Nu

179 Instruments Ltd., Nu Plasma II NP 214), and Sr isotope ratios were measured by

180 Thermo Finnigan Triton TIMS using procedures described in Weis et al. (2006,

181 2007). Additional details regarding sample preparation and analytical techniques

182 are given by Mullen and Weis (2015). Analytical reproducibility and correction

183 methods for radiogenic isotope data are described in Supplementary Table S2.

184 Tephra from sample CC was excluded from isotopic analyses because of clear 
185 evidence for crustal contamination (abundant quartz xenocrysts, partially melted 186 granitic xenoliths).

188 4. Results

$189 \quad 4.1$ MI major and trace element compositions

190 The olivine host crystals vary from Fo ${ }_{83}$ to Fo90 (Supplementary Table S1 and

191 S7). For each cinder cone, 11-17 MI were analyzed. The major element compositions

192 of the inclusions were corrected for post-entrapment crystallization (PEC) and Fe-

193 loss using Petrolog 3.1.1.3 (Danyushevsky and Plechov, 2011), using models for

194 olivine-melt equilibria from Ford et al. (1983) and oxidation state from Borisov and

195 Shapkin (1990). Concentrations of volatiles and trace elements that are

196 incompatible in the olivine hosts were corrected using the Petrolog results for the

197 major elements. Initial $\mathrm{Fe}$ contents were chosen based either on the $\mathrm{FeO}^{\mathrm{T}}$ of the bulk

198 tephra or the highest value of $\mathrm{FeO}^{\mathrm{T}}$ for $\mathrm{MI}$ from a particular cone. An average oxygen

199 fugacity of $\Delta \mathrm{QFM}+1$, determined using the partitioning of $\mathrm{V}$ between the $\mathrm{MI}$ and host

200 olivine using methods of Mallmann and O'Neill (2009), was used in the Petrolog

201 calculations. Calculated values of PEC vary from 0 to 14\%. Corrected MI

202 compositions overlap with the most primitive lavas previously analyzed in the

203 Lassen region (Fig. 2) and have MgO concentrations of 7.4-9.8 wt\% (Supplementary

204 Table S1). To estimate a primary melt composition for each cone, we added

205 equilibrium olivine (in $0.1 \mathrm{wt} \%$ increments) to the average MI composition from

206 each cone until the melt composition was in equilibrium with Fogo olivine (Table 1;

207 Ruscitto et al., 2010). The calculated primary melt compositions required 1-20\% 
208 olivine addition (Table 1). Although variability in mantle olivine compositions likely

209 exists beneath the Lassen region (Clynne, 1993; Borg et al., 1997), we assume Fo90

210 for simplicity and because there is little evidence for more refractory mantle

211 compositions, unlike the Mt. Shasta region to the north, where some lavas and

212 tephra have olivine up to Fo94 (Ruscitto et al., 2011).

213 The MI are dominantly medium-K CAB, with some that fall into the low-K

214 field (Fig. 2a), and compositionally similar to the bulk tephra compositions

215 (Walowski et al., 2015; Supplementary Fig. S2). Previous work in the Lassen region

216 has suggested that LKT and CAB magmas have different source regions (Clynne,

217 1993; Bacon et al., 1997). However, the low-K samples used in this study do not

218 display the lower LREE/HREE and LILE/HFSE values typical of the endmember LKT

219 volcanic rocks in this region (Fig. 2; see also Bacon et al., 1997). All samples used in

220 this study display trace element patterns similar to the regional CABs (Fig. 2),

221 suggesting that despite variability in major and trace element compositions, they

222 were enriched by a component derived from the downgoing slab.

$224 \quad$ 4.2 Magmatic volatile contents

225 Dissolved $\mathrm{H}_{2} \mathrm{O}$ contents of the MI, after correction for PEC and Fe loss, are

226 0.6-3.5wt\%. At individual cinder cones, a range in $\mathrm{H}_{2} \mathrm{O}$ concentrations is observed

227 and is likely due to differences in extent of pre-entrapment degassing (e.g., Johnson

228 et al., 2009) and/or post-entrapment hydrogen loss (Lloyd et al., 2013; Bucholz et al.,

229 2013). We do not observe correlations between relative MI size and $\mathrm{H}_{2} \mathrm{O}$ contents.

230 Because these processes decrease $\mathrm{H}_{2} \mathrm{O}$, the maximum measured $\mathrm{H}_{2} \mathrm{O} / \mathrm{K}_{2} \mathrm{O}$ ratio for 
231 each cone was used to estimate the initial $\mathrm{H}_{2} \mathrm{O}$ content $\left(\mathrm{H}_{2} \mathrm{O}_{\max }\right)$ of the magma

232 erupted at that cone. In the Lassen region, $\mathrm{H}_{2} \mathrm{O}_{\max }$ ranges from 1.3-3.4 wt\%. The

$233 \mathrm{H}_{2} \mathrm{O}_{\max }$ values were used to estimate the $\mathrm{H}_{2} \mathrm{O}$ concentrations in primary mantle-

234 derived melts using the olivine addition method described above, yielding values of

235 1.1-3.4 wt\% (Table 1). These values overlap with calculated primary melt $\mathrm{H}_{2} \mathrm{O}$

236 concentrations for basaltic and basaltic andesite melts from central Oregon (1.4-3.0

237 wt\%; Ruscitto et al., 2010). In contrast to $\mathrm{H}_{2} \mathrm{O}, \mathrm{Cl}$ is not affected by either pre-

238 entrapment degassing (except at very low pressures) or post-entrapment diffusive

239 effects. Concentrations of $\mathrm{Cl}$ in calculated primary melts range from $100-600 \mathrm{ppm}$,

240 except at BRM, where $\mathrm{Cl}$ values are as high as $2500 \mathrm{ppm}$ (Supplementary Table S1).

241 Similar to $\mathrm{H}_{2} \mathrm{O}, \mathrm{CO}_{2}$ concentrations are variable at individual cones and

242 reflect a combination of pre-entrapment degassing and post-entrapment loss. We

243 report the highest PEC-corrected $\mathrm{CO}_{2}$ contents from individual cinder cones, and

244 these range from 599-1493 ppm (Supplementary Table S1; Fogo corrected primary

245 melts $=521-1435 \mathrm{ppm}$; Table 1 ). It is important to note that these $\mathrm{CO}_{2}$ values

246 underestimate the initial $\mathrm{CO}_{2}$ concentration of the melt. Most MI analyzed in this

247 study contain a vapor bubble (presence /absence of vapor bubble noted in

248 Supplementary Table S1), and such bubbles typically contain a substantial fraction

249 (40-90\%) of the $\mathrm{CO}_{2}$ that was initially dissolved in the trapped melt (Wallace et al.,

250 2015; Moore et al., 2015). As a result, the $\mathrm{CO}_{2}$ contents of the MI are underestimates

251 of the magmatic $\mathrm{CO}_{2}$ content. Sulfur contents of PEC corrected MI range from 380-

2522140 ppm (Supplementary Table S4; Fogo corrected primary melts $=900-1600$ ppm;

253 Table 1). Samples BRVB, BPB, and BBL each have one MI that contains a small $(<5$ 
$254 \mu \mathrm{m}$ sphere) coexisting sulfide phase. Because post-entrapment Fe-loss can cause

255 sulfide saturation and decreasing sulfur in the residual melt (Danyushevsky et al.,

256 2002), these few individual MI may have lost some $S$ after entrapment. However,

257 there is no evidence to suggest this process had an effect on most MI, such as highly

258 variable S contents from an individual MI suite.

\section{$260 \quad 4.3$ Isotopic Compositions}

261 The average $\delta^{11} \mathrm{~B}$ ratios of MI from individual cones in the Lassen region

262 range from $-9.9 \%$ to $-2.4 \%$ (Fig. 3; Supplementary Table S3). These values overlap

263 with those measured for bulk rock samples from the southern Washington Cascades

264 (-9\%o to -0.4\%; Leeman et al., 2004) and MI from the Mt. Shasta region (Fig. 3; Rose

265 et al., 2001; LeVoyer et al., 2010). MI from the Cascades have lower B concentrations

266 and more negative $\delta^{11} \mathrm{~B}$ than those measured in other arcs, such as Kamchatka and

267 Mariana, where older oceanic crust subducts (Fig. 3; Ishikawa et al., 2001; Ishikawa

268 and Tera, 1999).

269 The $\mathrm{Sr}, \mathrm{Nd}, \mathrm{Hf}$, and $\mathrm{Pb}$ isotope ratios for bulk tephra samples overlap with

270 those previously determined for volcanic rocks in the Lassen Region (Fig. 4; Table 2).

272 5. Discussion

$273 \quad 5.1$ The source of volatiles in Lassen Region primitive magmas

$274 \quad$ Boron is a fluid mobile element that is present in higher concentrations in 275 subducted materials than the mantle, making it an excellent tracer of fluids from 276 subducting slabs (e.g., Tonarini et al., 2001). In addition, subducted materials such 
277 as sediment, oceanic crust, and serpentinitized mantle have $\delta^{11} \mathrm{~B}$ that is distinct

278 from the mantle wedge (e.g., Ishikawa and Nakamura, 1993). However, the Lassen

279 region MI have MORB-like to slightly elevated B isotopic compositions and low B

280 concentrations, which suggests that the sub-arc mantle receives little B from the

281 subducting slab (Fig. 3). This is probably the result of extensive dehydration of the

282 slab before it reaches sub-arc depths (Leeman et al., 2004; Manea et al., 2014).

283 However, geodynamic modeling and calculated metamorphic phase equilibria

284 suggest that, unlike $\mathrm{B}, \mathrm{H}_{2} \mathrm{O}$ can be carried to sub-arc depths beneath the Lassen

285 region by chlorite in the hydrated mantle portion of the slab (van Keken et al., 2011;

286 Walowski et al., 2015). Because nearly all B is released from hydrated peridotite

287 beneath the forearc during antigorite breakdown, chlorite-derived fluids contribute

288 little B to the subduction component (Spandler et al., 2014). This explains how the

289 slab beneath the Cascades can release a hydrous component that contains very little

290 B, such that primitive magmas formed in the wedge have B isotope ratios and

291 concentrations only slightly elevated compared to MORB.

292 Despite low $\mathrm{B}$ concentrations, $\mathrm{H}_{2} \mathrm{O}$ and $\mathrm{Cl}$ are high compared to MORB, which

293 requires that these volatiles are retained in the slab to greater depths than B.

294 Furthermore, strong correlations of $\mathrm{H}_{2} \mathrm{O}_{\max } / \mathrm{Ce}$ and $\mathrm{Cl} / \mathrm{Nb}$ with $\mathrm{Sr} / \mathrm{Nd}$ clearly

295 demonstrate that volatile and trace element enrichments are coupled and therefore

296 derived from the same process (Fig. 5). This observation is consistent correlations

297 globally and at other warm-slab subduction zones (Ruscitto et al., 2012). To quantify

298 this, we calculated the compositions of partial melts from two mantle endmembers

299 to which variable amounts of subduction component were added. Figure 5 shows 
300 good agreement between the model curves and the MI data, which indicates that

301 volatile and trace element variability between vents is the result of different

302 amounts of a subduction component added to a heterogeneous mantle wedge.

303 However, MI from cone BRM have lower $\mathrm{H}_{2} \mathrm{O}$ /Ce than predicted by the melting

304 model. This could be caused by variability in the $\mathrm{H}_{2} \mathrm{O}$ and trace element ratios of the

305 hydrous subduction component, or it could be that MI from this cone were strongly

306 affected by pre-entrapment degassing or post-entrapment $\mathrm{H}$ loss. $\mathrm{Cl} / \mathrm{Nb}$ provides a

307 more robust indication of initial volatile concentration because $\mathrm{Cl}$ is not affected by

308 diffusive loss and only degasses at very low pressure. Good agreement between data

309 and melting models for $\mathrm{Cl} / \mathrm{Nb}$ vs. $\mathrm{Sr} / \mathrm{Nd}$ provides support for the interpretation that

310 initial $\mathrm{H}_{2} \mathrm{O}$ concentrations are related to the amount of a subduction component

311 added to the mantle wedge beneath the arc and that the slab component has ratios

312 of $\mathrm{H}_{2} \mathrm{O}$ and $\mathrm{Cl}$ to LILE that are not highly variable (Fig. 5b, c). This suggests that BRM,

313 the sample with the highest $\mathrm{Sr} / \mathrm{Nd}$ and therefore largest amount of a subduction

314 component, has very low $\mathrm{H}_{2} \mathrm{O} / \mathrm{Ce}$ as a result of extensive degassing or post-

315 entrapment diffusive loss.

316 Volatile and trace element ratios for the central Oregon Cascades can also be 317 explained using the calculated melting curves, but require a more enriched mantle

318 source than Lassen magmas (Fig. 5a; Ruscitto et al., 2010). Interestingly, MI with the

319 highest values of Sr/Nd in both the Lassen region (BRM) and the Mt. Shasta region

320 do not have the highest values of $\mathrm{H}_{2} \mathrm{O} / \mathrm{Ce}$, but they do have the highest $\mathrm{Cl} / \mathrm{Nb}$ and

321 also have $\mathrm{Cl}$ concentrations significantly higher than other cones throughout the

322 Cascades (Ruscitto et al., 2012). As suggested above, these magmas likely 
323 experienced extensive degassing of $\mathrm{H}_{2} \mathrm{O}$ in the crust before $\mathrm{MI}$ entrapment

324 (evidenced by very low $\mathrm{CO}_{2}$ in many $\mathrm{MI}$ ), and/or were affected by post-entrapment

325 H loss. However, if the BRM and Shasta magmas had pre-degassing compositions

326 that fit the model curves in Figure 5a, they would have had initial $\mathrm{H}_{2} \mathrm{O}$

327 concentrations as high as $8-10 \mathrm{wt} \% \mathrm{H}_{2} \mathrm{O}$, in agreement with experimental phase

328 equilibria (Krawczynski et al., 2012). The Blanco Fracture zone, which separates the

329 Juan de Fuca and Gorda plates, may provide a pathway for deep serpentinization of

330 the upper mantle in the downgoing slab offshore of the Cascades, and has been

331 proposed as a source for the volatile-rich component beneath Mt. Shasta (Grove et

332 al., 2002; Manea et al., 2014). However, plate reconstructions suggest the Blanco

333 Fracture zone is not old enough to project beneath the arc (Wilson, 2002), and thus,

334 the causes of geochemical differences between the Mt. Shasta and Lassen regions

335 (Fig. 5) remain enigmatic.

336

$337 \quad 5.2$ The Lassen sub-arc mantle

$338 \quad$ Previous workers using trace elements and radiogenic isotopes in the Lassen

339 region found negative correlations between LILE/LREE ratios and ${ }^{87} \mathrm{Sr} /{ }^{86} \mathrm{Sr}$. This

340 requires that the modern subduction component is less radiogenic than the sub-arc

341 mantle and that the latter has anomalously high $\mathrm{Pb}$ and $\mathrm{Sr}$ isotope ratios (Borg et al.,

342 1997, 2002; Fig. 4). This observation by Borg et al. (1997) led to the conclusion that

343 the sub-arc mantle had been previously enriched by a sediment component, but

344 they suggested the enrichment must have occurred during an earlier, possibly

345 Mesozoic, subduction event because the $\mathrm{Pb}$ isotope ratios of young Pacific sediments 
346 were too low to explain the values. Subsequent research on sediments from the

347 Cascadia Basin (Fig. 4a; Carpentier et al., 2014; Mullen and Weis, 2015) has shown

348 that the sediments have radiogenic $\mathrm{Pb}$ isotopic ratios. Addition of such a bulk

349 sediment to depleted MORB mantle (DMM) could explain the anomalously

350 radiogenic $\mathrm{Pb}$ and $\mathrm{Sr}$ isotope ratios and trace element enrichments inferred for the

351 Lassen sub-arc mantle (Fig. 4a). However, it does not resolve the questions of when

352 or how the bulk sediment component was added, nor does it solve the puzzle

353 evident in Figs. 1c, d, and 4a that modern subduction seems to involve addition of a

354 less radiogenic slab component to an already isotopically enriched mantle wedge.

355 Addition of bulk sediment rather than sediment melt could be explained by mélange

356 diapirs that rise from the top of the subducted plate (e.g., Behn et al., 2011; Gerya et

357 al., 2003). Interestingly, the enriched mantle signature is restricted to the

358 southernmost Cascades, and may best be explained by either the addition of bulk

359 sediment to the mantle wedge during the accretionary events which produced the

360 Klamath Mountains terranes from 130-260 Ma (Irwin and Wooden, 1999) or during

361 subduction related to Sierra Nevada magmatism. Although the cause of the mantle

362 enrichment in the Lassen (and Shasta) region is unclear, the data suggests that this

363 component is distinct from the modern subduction component (Fig. 4). Therefore, in

364 subsequent models and interpretations, we consider the enriched mantle as a single

365 component and focus on the modern, volatile-rich and unradiogenic subduction

366 component that is evident in the Lassen-region mafic magmas. 
370 three component mixing between DMM, sediment melts, and oceanic crust melts

371 (Fig. 4a; Mullen and Weis, 2015). However, the low Sr/Nd magmas in the Lassen

372 region cannot be explained by mixing of the same components, and the strong

373 negative correlation of the Lassen data (Fig. 4a) suggests the magmas are dominated

374 by two components - enriched sub-arc mantle and subducted MORB crust - with a

375 lesser role for sediment melt (Fig. 4b). These observations suggest that low-Sr/Nd

376 magmas in the Lassen region reflect their derivation from a sub-arc mantle with an

377 isotopically-enriched character, as explained in the previous section. New

378 radiogenic isotope data from this study overlap with previously published data (Fig.

379 4). Because elevated $\mathrm{H}_{2} \mathrm{O} / \mathrm{Ce}, \mathrm{Cl} / \mathrm{Nb}$, and $\mathrm{Sr} / \mathrm{Nd}$ ratios are related to subduction

380 component addition, our data confirm that the subduction component has a MORB-

381 like isotopic composition, with less radiogenic $\mathrm{Sr}$ and $\mathrm{Pb}$ than the Lassen sub-arc

382 mantle. In its isotopic characteristics, the subduction component is similar to

383 offshore Gorda Ridge MORB (Davis et al., 2008).

$384 \quad$ Melting of subducted MORB crust was discounted by Borg et al. (1997)

385 because melting of dry eclogitized oceanic lithosphere requires higher temperatures

386 than expected for the slab top at sub-arc depths. Grove et al. (2002) discounted slab

387 melting beneath Shasta, where similar isotopic relationships are observed (Fig. 4),

388 because models of hydrous peridotite melting could reproduce the observed major

389 element compositions of primitive volcanic rocks in that region. Recent work by

390 Walowski et al. (2015) interpreted the light D/H values of MI from the Lassen region

391 as resulting from final dehydration of chlorite in the hydrated upper mantle portion 
392 of the downgoing slab. This provides a mechanism to deliver $\mathrm{H}_{2} \mathrm{O}$ to the basaltic slab

393 top and drive wet slab melting beneath the arc, as proposed by Till et al. (2013),

394 Kimura et al. (2014), and Spandler and Pirard (2014).

$395 \quad$ To test this hypothesis, we calculated mixing and partial melting models

396 involving sub-arc mantle and a partial melt of Gorda MORB (Fig 4b, c). Because

397 temperatures of the plate top are at or above the wet MORB and wet sediment solidi

398 (Schmidt and Poli, 1998; Herman and Spandler, 2006), we assume the subduction

399 components are partial melts rather than aqueous fluids (Cooper et al., 2012;

400 Ruscitto et al., 2012; Kimura et al., 2014; Walowski et al., 2015). Our use of

401 unaltered Gorda MORB as the dominant slab component requires that the most

402 altered part of the slab (which contain seawater-derived $\mathrm{Sr}$ ) loses much of its $\mathrm{Sr}$

403 during dehydration beneath the forearc during transition to eclogite (Walowski et

404 al., 2015). Because $\mathrm{Sr} / \mathrm{Nd}$ is an indicator of subduction enrichment, primitive basalts

405 with the lowest $\mathrm{Sr} / \mathrm{Nd}$ values should be most representative of the Lassen sub-arc

406 mantle. These samples exhibit a small range of $\mathrm{Sr}, \mathrm{Nd}$, and $\mathrm{Pb}$ isotope ratios which is

407 probably indicative of mantle heterogeneity beneath the arc (Borg et al., 1997;

408 2002). We thus use a range in sub-arc mantle compositions (Fig. $4 ;{ }^{87} \mathrm{Sr} /{ }^{86} \mathrm{Sr}=$

$4090.7039-0.7043$ and ${ }^{208} \mathrm{~Pb} /{ }^{204} \mathrm{~Pb}=38.512-38.782$ ). Figure $4 \mathrm{~b}$ and $\mathrm{c}$ show curves

410 that represent melts of sub-arc mantle after addition of variable amounts of Gorda

411 MORB melt, the results of which suggest 1-10 wt\% addition of the slab melt.

$412 \quad$ Our proposed mechanism for slab melting relies on breakdown of chlorite in

413 the lithospheric mantle of the downgoing plate. However, in the model shown in

414 Figure $4 \mathrm{~b}$ and $\mathrm{c}$, the chemical composition of this chlorite-derived fluid component 
415 has been neglected. Fluids from the breakdown of chlorite at sub-arc depths have

416 some distinct trace element characteristics (e.g., elevated LREE/HREE) but, overall,

417 are solute poor (Spandler et al., 2014). As a result, chlorite-derived fluids will have

418 little effect on the trace element composition of the magmas formed by flux melting

419 of the upper oceanic crust. We therefore conclude that fluids derived from chlorite

420 breakdown in the hydrated mantle portion of the slab dominantly contribute $\mathrm{H}_{2} \mathrm{O}$ to

421 the system but do not impart a distinctive trace element signature.

422

\section{$423 \quad 5.4$ The role of sediment melts and crustal assimilation}

424 Although the model results in Figures $4 \mathrm{~b}$ and $4 \mathrm{c}$ can explain a majority of the

425 compositions, some values of $\mathrm{Sr}$ and $\mathrm{Pb}$ isotopes are above the model predictions.

426 There are three possible explanations for these small offsets: 1) contributions from

427 zones of altered MORB in the downgoing plate that partially retained their altered

428 isotopic signature after complete dehydration, 2) involvement of small proportions

429 of a sediment melt component (Borg et al., 1997; 2002), and/or 3) contamination by

430 crustal material. To further distinguish sediment and slab melt contributions, we

431 use Th/La as a discriminant because of the high Th concentrations in sediments

432 relative to MORB and sub-arc mantle (Fig. 4d; Plank et al., 2005). The mixing model

433 in Figure $4 \mathrm{~d}$ shows that $\mathrm{Th} /$ La variations in primitive Lassen magmas can result

434 from addition of $<10 \%$ of a subduction component made up of variable proportions

435 of sediment and MORB melts. At all but two cinder cones, MI trace element

436 compositions suggest that the slab component is dominated by melts of basaltic

437 oceanic crust and contains $<30 \%$ sediment melt. Two cinder cones (BPB and CC) 
438 have larger apparent contributions from sediment melts. Cinder Cone, in particular,

439 contains the highest Th/La values from our dataset. However, the bulk lava and

440 tephra at this cone contain abundant quartz xenocrysts and variably melted granitic

441 xenoliths, which are clear indications of crustal contamination. This sample was

442 therefore excluded from radiogenic isotope analyses. We also note that MI from the

443 Lassen region samples have lower Th/La values on average than many of the

444 published bulk rock analyses from this area (Fig. 4d; Borg et al., 1997, 2002). This

445 could be because MI are trapped at depth, before even minor crustal contamination

446 occurs. Previous workers in the Lassen region interpreted unradiogenic Os isotopic

447 compositions in the most primitive basalts and basaltic andesites as evidence for

448 minimal contamination by continental crust (Borg et al., 1997, 2000). However, very

449 high Th concentrations in the granitic basement rocks (Cecil et al., 2012) make it

450 possible for small amounts of contamination to increase $\mathrm{Th} / \mathrm{La}$ ratios to make it

451 difficult to differentiate between sediment melt and contamination.

452

$453 \quad 5.5$ Modeling slab melt addition and the $\mathrm{Sr} / \mathrm{Y}$ adakite signature

$454 \quad$ The studied Lassen magmas have basaltic major element compositions and

455 are not high-Mg andesites as might be expected for magmas derived by slab melting

456 (Kelemen et al., 2003). To test whether the major and trace element compositions of

457 these magmas can be reproduced by slab melt addition to the mantle wedge, we

458 used pMELTS (Ghiorso et al., 2002) to compare the effects of fluid vs. hydrous melt

459 addition (Eiler et al., 2000) to the wedge at temperatures and pressures expected

460 for the Lassen sub-arc mantle. We created the starting bulk compositions by adding 
461 various amounts of either a dacitic slab melt (Klimm et al., 2008) or pure $\mathrm{H}_{2} \mathrm{O}$ to a

462 primitive mantle composition (MM3; Baker and Stolper, 1994). The pMELTS

463 program was used to determine the phase equilibria of the bulk mixture from 900-

$4641400^{\circ} \mathrm{C}$ at a pressure of $1.5 \mathrm{GPa}$. These values are based on temperatures from

465 geodynamic model results for the Lassen region (Walowski et al., 2015), beginning

466 at the slab-wedge interface to $\sim 100^{\circ} \mathrm{C}$ hotter than peak temperatures expected in

467 the wedge. See Supplementary Discussion S3 for further details.

$468 \quad$ Melt fractions for both the hydrous-melt-fluxed and fluid-fluxed peridotite

469 cases are nearly indistinguishable (Supplementary Fig. S3). This suggests that for a

470 given mantle composition, the amount of $\mathrm{H}_{2} \mathrm{O}$ supplied to the mantle controls the

471 degree of melting irrespective of whether the $\mathrm{H}_{2} \mathrm{O}$ is added as melt or fluid,

472 consistent with experiments of Mallik et al. (2015). Figure 6 shows the major

473 element compositions of partial melts resulting from various amounts of slab melt

474 and aqueous fluid addition to the mantle wedge. For small amounts of slab melt

475 addition (1-3 wt\%), the major element compositions of resulting basaltic melts are

476 similar to those of the aqueous fluid addition case. This indicates that equilibrium

477 between partial melt and residual mantle largely controls the major element

478 composition of the final melt. Primary magma compositions calculated from the MI

479 data overlap with the pMELTS model results (Fig. 6), demonstrating that hydrous-

480 melt-fluxed melting of the mantle wedge is a viable explanation for the production

481 of these magmas.

482 One hallmark of slab melt is high $\mathrm{Sr} / \mathrm{Y}$ caused by the presence of garnet,

483 which makes up a large proportion of eclogitized MORB in the subducted plate 
484 (Defant and Drummond, 1990). Most Lassen magmas, however, do not have high

$485 \mathrm{Sr} /$ Y values compared with the global array of adakites (Fig 7). Using the mixed

486 mantle compositions and melt fractions from the pMELTS models, melting curves in

487 Figure $8 \mathrm{~b}$ show that for small amounts of slab melt addition (1-10\%), the Sr/Y ratio

488 is dampened due to addition of $Y$ from the spinel peridotite mantle component. This

489 yields values that overlap with values measured in MI from all but one sample

490 (BRM) from the Lassen region (Fig. 8b). The results are consistent with calculations

491 by Kelemen (1993) showing that peridotite-melt reaction produces melts with

492 lower LREE/HREE than the initial slab melts. Our model results suggest that high

$493 \mathrm{Sr} / \mathrm{Y}$ adakitic signatures are only retained in arc magmas if slab melt addition is $>10$

494 wt\%. Larger proportions of slab melt addition are thus required to explain the high

$495 \mathrm{Sr} / \mathrm{Y}$ value of sample BRM, consistent with estimates of $\sim 10 \%$ slab melt addition

496 inferred from radiogenic isotopes (Fig. 4). The high-Mg andesites from the Lassen

497 (M. Clynne, unpub. data) and Shasta regions that have higher values of Sr/Y ( 150;

498 Ruscitto et al., 2011) could therefore be produced by larger amounts of hydrous slab 499 melt addition to the mantle wedge.

$500 \quad$ Although most primitive Cascade arc magmas do not have particularly high

$501 \mathrm{Sr} / \mathrm{Y}$ compared to adakites, they do have other characteristics that indicate melting

502 in the presence of garnet when compared to the global array of basaltic arc magmas.

503 For example, primitive magmas from warm-slab subduction zones (Cascades,

504 Mexico) display elevated LREE/HREE and MREE/HREE (e.g. La/Yb and Dy/Yb;

505 Walowski et al., 2015 and Turner et al., 2015, respectively) and coupled high

$506{ }^{176} \mathrm{Hf} /{ }^{177} \mathrm{Hf}$ and ${ }^{143} \mathrm{Nd} /{ }^{144} \mathrm{Nd}$ with lower values of $\mathrm{Lu} / \mathrm{Hf}$ (Cai et al., 2014) when 
507 compared to arcs associated with older oceanic crust. These relationships

508 demonstrate that partial melts of subducted oceanic crust play an increasingly

509 important role in the formation of magmas in arcs associated with young oceanic

510 crust.

511

512 6. Model for magma generation beneath the southern Cascade arc

513 Our results suggest that southern Cascade magmas are produced by a multi-

514 stage process involving fluid-flux melting of the basaltic slab top ( \pm lesser sediment)

515 and ascent of this hydrous melt into the mantle wedge. Figure 8 shows a schematic

516 interpretation of this process based on the thermo-petrologic model results of

517 Walowski et al. (2015), the shear wave velocity model from Liu et al. (2012), and the

518 magnetotelluric data from Wannamaker et al. (2014). In our model, $\mathrm{H}_{2} \mathrm{O}$ is retained

519 in the hydrated upper mantle portion of the downgoing slab to greater depths than

520 those at which $\mathrm{H}_{2} \mathrm{O}$ is lost from the slab top (Fig. 9). Final chlorite breakdown occurs

521 in the slab interior when the slab top reaches $\sim 75-80 \mathrm{~km}$. At this depth, the upper

522 portions of the slab are above the $\mathrm{MORB}+\mathrm{H}_{2} \mathrm{O}$ solidus, and thus should melt when

523 fluxed by rising chlorite-derived fluids (e.g., Spandler and Pirard, 2013). The

524 resulting hydrous dacitic melts (Klimm et al., 2008) then rise into the overlying

525 mantle wedge and react with the surrounding mantle to produce hydrous, calc-

526 alkaline, basaltic to basaltic andesite melts (Fig. 7).

527 As a further test of this model, we determined whether breakdown of

528 chlorite can supply enough $\mathrm{H}_{2} \mathrm{O}$ to balance the flux of $\mathrm{H}_{2} \mathrm{O}$ from Cascade arc

529 magmatism. Previous work in Nicaragua (Ranero et al., 2003) and other arcs has 
530 provided evidence for hydration of the deep slab and the importance of fluids

531 released from the deep slab in the production of arc magmas (e.g., Spandler and

532 Pirard, 2013). For the Juan de Fuca plate, higher temperatures at Moho depths

533 caused by the younger slab age may limit the extent of serpentinization (Nedimovic

534 et al., 2009), but no data are available for the Gorda plate to assess upper mantle

535 hydration. Due to this uncertainty, Walowski et al. (2015) conservatively assumed 2

$536 \mathrm{~km}$ of hydration below the Moho of the downgoing plate and a bulk $\mathrm{H}_{2} \mathrm{O}$

537 concentration of $2 \mathrm{wt} \%$ for the hydrated peridotite. Using these model parameters,

538 the $\mathrm{H}_{2} \mathrm{O}$ flux contributed by chlorite breakdown in the slab interior is estimated to

539 be $\sim 1-2 \times 10^{6} \mathrm{~kg} / \mathrm{km}$ arc length $/ \mathrm{yr}$. For the magmatic flux of $\mathrm{H}_{2} \mathrm{O}$ from the Cascades,

540 we use the estimate from Ruscitto et al. (2012). This method, which includes

541 extrusive and intrusive magma fluxes and utilizes volatile contents from the central

542 Oregon Cascades (which overlap with those from the Lassen region), yields a

543 maximum $\mathrm{H}_{2} \mathrm{O}$ flux of $1.93 \times 10^{6} \mathrm{~kg} / \mathrm{km} / \mathrm{yr}$. This estimate agrees very well with the

544 flux from the thermo-petrologic model, demonstrating that fluids derived from the

545 breakdown of chlorite in the hydrated upper mantle portion of the slab may be

546 sufficient to produce observed volatile fluxes in the Cascade arc.

547 The thermo-petrologic model results of Walowski et al. (2015) predict two

548 main pulses of fluid from the downgoing slab associated with 1) the final

549 breakdown of hydrous phases during eclogitization of the oceanic crust, and 2) the

550 final breakdown of chlorite in the hydrated mantle portion of the slab (Fig. 9). The

551 first, more shallow pulse of fluid release correlates well with the location of a low-

552 resistivity anomaly beneath the forearc (Wannamaker et al., 2014), and likely 
553 reflects a region of serpentinization of the cold nose of the mantle wedge. The

554 second, which causes flux melting of the slab top, agrees well with regions of low

555 shear wave velocity beneath the Lassen region (Liu et al., 2012). The shape of the

556 low shear wave velocity region is consistent with models of fluid migration into the

557 mantle wedge that suggest that for most values of wedge permeability, slab dip, and

558 convergence velocity there is a net migration of fluids and melts away from the

559 trench (Cagnioncle et al., 2007). This implies that arc magmas will inherit a slab

560 signature from a region of the slab that is slightly up-dip of the region that lies

561 directly beneath the arc. Therefore, patterns of decreasing amounts of a subduction

562 component towards the rear-arc, as observed in the geochemical data (Clynne,

563 1993; Borg et al., 1997; 2002), are consistent with the model in Figure 9.

564

\section{7. Conclusions}

566 The process of melt generation in warm-slab suduction zones, such as

567 Cascadia, has been debated due to the high slab surface temperatures and extensive

568 slab dehydration predicted by geodynamic and geochemical models. Our results

569 provide strong evidence that magma production in the southern Cascade arc is

570 driven by hydrous slab melt addition to the mantle wedge. Low B concentrations

571 and MORB-like B isotope ratios indicate that extensive dehydration of the plate

572 occurs before it reaches sub-arc depths. However, volatile concentrations and

573 correlations of volatile and trace element ratios $\left(\mathrm{H}_{2} \mathrm{O} / \mathrm{Ce}, \mathrm{Cl} / \mathrm{Nb}, \mathrm{Sr} / \mathrm{Nd}\right)$ show that

574 Lassen magmas have been enriched by variable amounts of addition of a hydrous

575 subduction component. Correlation of fluid mobile trace elements and radiogenic 
576 isotopes demonstrates that the modern subduction component in the southern

577 Cascades is less radiogenic than the sub-arc mantle wedge and must be dominantly

578 derived from a partial melt of subducting Gorda MORB, with a minor contribution

579 from subducted sediment melts. The pMELTS model results show that hydrous

580 melt-fluxed melting of the mantle wedge can produce basaltic magmas with similar

581 major element compositions to those measured in Lassen MI. Our results provide

582 further evidence that chlorite-derived fluids from the deep slab interior can flux-

583 melt the oceanic crust, producing hydrous slab melts that migrate into the overlying

584 mantle, where they react with peridotite to induce further melting. The combined

585 observations provide new insight on element recycling at subduction zones and

586 demonstrate that partial melts of subducted oceanic crust play an important role in

587 arcs associated with the subduction of young oceanic crust.

589 Acknowledgements

590 We thank Adam Kent for assistance with LA-ICP-MS measurements, Brian

591 Monteleone for assistance with SIMS, John Donovan for assistance with EPMA, Erik

592 Hauri for providing B-isotope standards, Nicole Marsh for carrying out the

593 radiogenic isotope analyses at PCIGR, and Ilya Bindeman for their helpful comments.

594 KJW thanks Angela Seligman, Ellen Aster, and Stan Mordensky for assistance in the

595 field. We appreciate the constructive reviews of Catharine Chauvel, Maxim

596 Portnyagin, and Dawnika Blatter, and assistance from the editor, Tamsin Mather.

597 Funding was provided by the National Science Foundation (EAR-1119224 and EAR-

598 1019848). 


\section{$600 \quad$ Figure Captions}

601 Figure 1: a) Regional map of the Northwestern United States showing major tectonic

602 boundaries. The Cascade volcanic arc is defined by the major peaks (black triangles).

603 Lassen Peak is highlighted with a red triangle. Black arrows show convergence

604 direction and are labeled with the convergence rate relative to North America. b)

605 Larger scale map of the Lassen region with locations of vents sampled in this study

606 (BRVB: Basalt of Round Valley Butte; BPB: Basalt of Poison Butte; BRM: Basalt of

607 Red Mountain; BBL: Basalt of Big Lake; BAS-44: Basalt of Hwy 44; BPPC: Basalt of

608 Paine Parasitic Cone; BORG: Basalt of Old Railroad Grade; CC: Cinder Cone; see Table

6091 for details) and previously sampled by Clynne (1993) and Borg (1995; gray

610 diamonds). Lassen Peak (large white triangle), outcropping basement rocks (shaded

611 pink areas), major highways (thin black lines), and large lakes (shaded blue regions),

612 are also highlighted. Distance from the trench vs. c) $\mathrm{Sr} / \mathrm{Nd}$ and d) ${ }^{87} \mathrm{Sr} /{ }^{86} \mathrm{Sr}$ for

613 samples in this study (colored symbols) and Borg et al. (1997; gray diamonds).

614 Symbols and colors for individual cinder cones are consistent throughout the

615 manuscript.

616

617 Figure 2: a) Average MI trace element composition for each cone normalized to 618 normal-MORB (N-MORB; Sun and McDonough, 1989). Shown for comparison are 619 endmember compositions (CAB, Borg et al., 1997; HAOT, Bacon et al. 1997). b) $\mathrm{K}_{2} \mathrm{O}$

620 and $\mathrm{SiO}_{2}$ contents of individual MI (corrected to equilibrium with host olivine and, 
621 normalized on a volatile-free basis) compared with bulk rock analyses from Clynne 622 (1993; gray diamonds).

623

624 Figure 3: Boron isotope compositions of Lassen MI. Each data point (symbols as in 625 Fig. 1) represents an average of 4-8 individual MI from a given cone. Symbol size 626 represents $\geq 1 \mathrm{SE}$ (Table 2). Shown for comparison are data from the southern 627 Washington Cascades (Leeman et al., 2004; filled squares, whole-rock analyses) Mt. 628 Shasta (Rose et al., 2001, open circles; individual MI; LeVoyer et al., 2010, filled 629 circles, MI), the Marianas (Ishikawa, 2001), and Kamchatka (Ishikawa and Tera, 630 1999). Dashed black curve represents basaltic magmas formed by flux melting of 631 depleted MORB mantle by hydrous slab fluid (Marschall, 2007). 632

633 Figure 4: Bulk tephra isotopic compositions and average trace element compositions 634 from MI (Table 2; filled symbols as in Figure 3;) and bulk tephra (open symbols; 635 Walowski et al., 2015; no bulk tephra data available for BRM [purple]). a) ${ }^{87} \mathrm{Sr} /{ }^{86} \mathrm{Sr}$ 636 vs. Sr/Nd; the North Cascades (pink shaded region in panel a; Mullen and Weis, 637 2015), and Mt. Adams (red shaded region in panel a; Jicha et al., 2009) are shown for 638 comparison. Dashed lines connect the three components most likely to contribute to 639 magma formation, as described in previous work (Mullen and Weis, 2015), but are 640 not mixing models. Compositional similarity of bulk tephra and MI is described in 641 Supplementary Discussion S2 and Fig. S2, which provides support for plotting MI 642 compositions with bulk tephra radiogenic isotopes. Isotopic composition of BRM is 643 from Borg et al. (1997), not this study. CC was omitted due to evidence for crustal 
644 contamination (see text). Bulk lava analyses from the Lassen and Shasta regions

645 (Borg et al., 1997; Grove et al., 2002, respectively). b) Again, ${ }^{87} \mathrm{Sr} /{ }^{86} \mathrm{Sr}$ vs. $\mathrm{Sr} / \mathrm{Nd}$;

646 symbols as in a), now with North Cascade sediment (yellow shaded region;

647 Carpentier et al., 2013, 2014) and northern Sierran granites (gray shaded region;

648 Cecil et al., 2012) highlighted to show components that may contribute to trace

649 element and radiogenic isotope variability of samples. Melting models (dashed

650 lines) calculated using the batch melting equation for a range in mantle sources

651 (calculated for the Lassen sub-arc mantle; see Discussion section 5.2 for details)

652 mixed with 2, 5, and $10 \mathrm{wt}$.\% (labeled on modeled curves) of a slab melt derived by

$6535 \%$ partial melting of Gorda MORB (Davis et al., 2008; partition coefficients [4 GPa,

$6541000^{\circ} \mathrm{C}$ ] from Kessel et al., 2005a; Supplementary Table S6). Bulk partition

655 coefficients for mantle melting were calculated for a spinel peridotite assemblage

$65653 / 30 / 12 / 5-0 l / 0 p x / C p x / S p$ (Ruscitto et al., 2010) using partition coefficients of

657 Eiler et al. (2005) for Sr and Nd (Supplementary Table S6). Melt fractions were

658 derived from pMELTS model results (for a given temperature and amount of slab

659 melt addition; Fig. 6). c) ${ }^{208} \mathrm{~Pb} /{ }^{204} \mathrm{~Pb}$ vs. Sr/Nd; symbols and shaded regions as in

660 a,b), and mixing/melting model as in b). d) MI data only (from this study), and

661 Lassen bulk lava compositions from Borg et al. (1997). Curves represent partial

662 melting models for the Lassen sub-arc mantle (composition inferred from bulk rock

663 samples with smallest amount of apparent subduction component; see Discussion

664 section 5.2) mixed with either sediment partial melts (upper curves) or partial melts

665 from the basaltic slab (lower curves). The sediment partial melts were assumed to

666 be generated by either 5\% partial melting (large filled gray diamond) or 20\% partial 
667 melting (small filled gray diamond) of N. Cascade sediment (partition coefficients

668 from Kessel et al., 2005a; Supplementary Table S6). The basaltic slab partial melts

669 likewise were assumed to be generated by either 5\% partial melting (large filled

670 black diamond) or 20\% partial melting (small filled black diamond) of Gorda MORB

671 (partition coefficients from Kessel et al., 2005a; Supplementary Table S6). The gray

672 shaded regions show the range of melt compositions created in the mantle by

673 addition of $<10 \mathrm{wt} \%$ total of these subduction components (made with various

674 proportions of MORB vs. sediment melts) to the mantle wedge. The lines with tick

675 marks (in 10\% increments) connecting the mixing curves are labeled with the

676 proportion of the subduction component derived from sediment partial melt, with

677 the remainder of the subduction component derived from the slab melt.

678

679 Figure 5: a) $\mathrm{H}_{2} \mathrm{O} / \mathrm{Ce}$ vs. $\mathrm{Sr} / \mathrm{Nd}$ in MI. Data points are shown for MI that contain $\mathrm{H}_{2} \mathrm{O}$

680 concentrations within $0.5 \mathrm{wt} \%$ of the $\mathrm{H}_{2} \mathrm{O}_{\max }$ value for each cone, as these values

681 represent the least degassed compositions. b) Cl/Nb vs. Sr/Nd (all MI; corrected)

682 and c) $\mathrm{Cl} / \mathrm{Nb}$ vs. Sr/Nd (average MI values for each cone; $\mathrm{y}$-axis is extended to higher

683 values than in panel b). In a and c, data from central Oregon (Ruscitto et al., 2010;

684 solid blue circles enclosed in light blue shaded field] and Mt. Shasta [Ruscitto et al.,

685 2008; primitive basaltic andesite (PBA): solid gray triangles enclosed in gray shaded

686 field; high-Mg andesites (HMA): open gray triangles enclosed in a gray shaded field)

687 are shown for comparison. Black lines represent 10\% partial melts of two

688 endmember mantle compositions (DMM; Workman and Hart, 2005; and average

689 central Oregon mantle; Ruscitto et al., 2010) mixed with variable amounts of a 
690 hydrous subduction component (gray diamond in a; calculated using methods of

691 Portnyagin et al., 2007, based on primary magma composition of sample BORG;

692 Table 1). The gray bar represents the range in sub-arc mantle compositions

693 determined by Walowski et al. (2015). MI that experienced degassing before

694 entrapment or post-entrapment $\mathrm{H}$ loss will deviate from the melting curves as

695 indicated by the black arrow in panel a.

696

697 Figure 6: pMELTS model results compared with calculated primary magma

698 compositions from each cone (Table 1). a) $\mathrm{H}_{2} \mathrm{O}$, b) $\mathrm{K}_{2} \mathrm{O}+\mathrm{Na}_{2} \mathrm{O}$, c) $\mathrm{CaO}$ and d) $\mathrm{Al}_{2} \mathrm{O}_{3}$

699 wt\% vs. $\mathrm{SiO}_{2}$ (all major elements are normalized volatile free). Phase equilibria were

700 calculated using pMELTS with a starting bulk composition of a mantle source (MM3;

701 Baker and Stolper, 1994) mixed with 1, 2, 5, or $10 \%$ of either pure $\mathrm{H}_{2} \mathrm{O}$ (dashed

702 curves) or a hydrous dacite melt (solid curves; dacite melt from Klimm et al., 2008)

703 at $1.5 \mathrm{GPa}$. Each curve represents melting model results from $900-1400^{\circ} \mathrm{C}$, with

704 major element compositions normalized volatile free. See Supplementary

705 Discussion S3 and Supplementary Table S6 for model parameters and further

706 details.

707

708 Figure 7: Average values of Sr/Y and Y for each cone (Table 2) compared to global

709 range of adakite compositions (GEOROC database) and experimental partial melts of

710 eclogite (Klimm et al., 2008). Solid and dashed curves represent modeled mantle

711 melt compositions for various amounts of slab melt addition from $900-1350^{\circ} \mathrm{C}$ at 1.5

712 GPa. Modeled Sr and Y were calculated using the batch melting equation for a 
713 mantle source (calculated for the Lassen sub-arc mantle) mixed with 2, 5, and 10\%

714 (labeled on model curves) of a partial melt of Gorda MORB (as in Fig. 4d;

715 Supplementary Table S6). Bulk partition coefficients were calculated for a spinel

716 peridotite assemblage 35/30/12/5-0l/Opx/Cpx/Sp using mineral partition

717 coefficients of Eiler et al. (2005) for Sr and Eiler et al. (2001) for Y (Supplementary

718 Table S6). Melt fractions were derived from pMELTS model results (for a given

719 temperature and amount of slab melt addition; Fig. S3).

720

721 Figure 8: Schematic diagram depicting the petrogenesis of Lassen region magmas.

722 Chlorite-derived fluids from the deep slab interior beneath the forearc vents (small

723 blue arrows) drive flux-melting of the oceanic crust (red colored area), producing

724 hydrous slab melts that migrate into the overlying mantle (red arrows), where they

725 react with peridotite to induce further melting. The location of hydrous phase

726 stability in the downgoing slab (dark blue shaded region) and main pulses of fluid

727 release from the slab (small light blue arrows) are based on the thermo-petrologic

728 model results of Walowski et al. (2015). Area of low-velocity (dark and light orange

729 shaded regions for latitudes $41^{\circ}$ and $40.6^{\circ}$ of the 2D models, respectively) based on

730 shear wave velocity model of Lui et al. (2012). Green shaded region shows the

731 location of low resistivity from Wannamaker et al. (2014).

732

733

\section{References}


736 Bacon, C. R., Bruggman, P. E., Christiansen, R. L., Clynne, M. A., Donnelly-Nolan, J. M.,

737 \& Hildreth, W. (1997). Primitive magmas at five Cascades volcanic fields: melts from

738 hot, heterogeneous sub-arc mantle. Canadian Mineralogist, 35, 397-424.

739

740 Baker, M. B., \& Stolper, E. M. (1994). Determining the composition of high-pressure

741 mantle melts using diamond aggregates. Geochimica et Cosmochimica Acta, 58(13),

$742 \quad 2811-2827$.

743

744 Behn, M. D., Kelemen, P. B., Hirth, G., Hacker, B. R., \& Massonne, H. J. (2011). Diapirs

745 as the source of the sediment signature in arc lavas. Nature Geoscience, 4(9), 641-

746646.

747

748 Berge, P. A., \& Stauber, D. A. (1987). Seismic refraction study of upper crustal

749 structure in the Lassen Peak Area, northern California. Journal of Geophysical

750 Research: Solid Earth (1978-2012), 92(B10), 10571-10579.

751

752 Borg, L. E., Clynne, M. A., \& Bullen, T. D. (1997). The variable role of slab-derived

753 fluids in the generation of a suite of primitive calc-alkaline lavas from the

754 southernmost Cascades, California. Canadian Mineralogist, 35, 425-452.

755

756 Borg, L. E., Brandon, A. D., Clynne, M. A., \& Walker, R. J. (2000). Re-Os isotopic

757 systematics of primitive lavas from the Lassen region of the Cascade arc, California.

758 Earth and Planetary Science Letters, 177(3), 301-317. 
760 Borg, L. E., Blichert-Toft, J., \& Clynne, M. A. (2002). Ancient and modern subduction

761 zone contributions to the mantle sources of lavas from the Lassen region of

762 California inferred from Lu-Hf isotopic systematics. Journal of Petrology, 43(4), 705-

763723.

764

765 Borisov, A. A., \& Shapkin, A. I. (1990). A new empirical equation rating Fe3+/Fe2+ in

766 magmas to their composition, oxygen fugacity, and temperature. Geochem. Int, 27(1),

$767 \quad 111-116$.

768

769 Bucholz, C. E., Gaetani, G. A., Behn, M. D., \& Shimizu, N. (2013). Post-entrapment

770 modification of volatiles and oxygen fugacity in olivine-hosted melt inclusions. Earth

771 and Planetary Science Letters, 374, 145-155.

772

773 Cagnioncle, A. M., Parmentier, E. M., \& Elkins-Tanton, L. T. (2007). Effect of solid

774 flow above a subducting slab on water distribution and melting at convergent plate

775 boundaries. Journal of Geophysical Research: Solid Earth (1978-2012), 112(B9).

776

777 Cai, Y., LaGatta, A., Goldstein, S. L., Langmuir, C. H., Gómez-Tuena, A., Martín-del

778 Pozzo, A. L., \& Carrasco-Núñez, G. (2014). Hafnium isotope evidence for slab melt

779 contributions in the Central Mexican Volcanic Belt and implications for slab melting

780 in hot and cold slab arcs. Chemical Geology, 377, 45-55. 
782 Carpentier, M., Weis, D., \& Chauvel, C. (2013). Large U loss during weathering of

783 upper crust: the sedimentary record. Chemical Geology, 340, 91-104.

784

785 Carpentier, M., Weis, D., \& Chauvel, C. (2014). Fractionation of Sr and Hf isotopes by 786 mineral sorting in Cascadia Basin terrigenous sediments. Chemical Geology, 382, 6778782.

788

789 Cecil, M. R., Rotberg, G. L., Ducea, M. N., Saleeby, J. B., \& Gehrels, G. E. (2012).

790 Magmatic growth and batholithic root development in the northern Sierra Nevada, 791 California. Geosphere, 8(3), 592-606.

792

793 Clynne, M. A. (1993). Geologic studies of the Lassen volcanic center, Cascade Range,

794 California. University of California, Santa Cruz. Ph.D. Dissertation. 795

796 Clynne, M. A., \& Muffler, L. J. P. (2010). Geologic map of Lassen Volcanic National 797 Park and vicinity, California. Scientific Investigations Map SIM-2899, US Geological 798 Survey. 799

800 Cooper, L. B., Ruscitto, D. M., Plank, T., Wallace, P. J., Syracuse, E. M., \& Manning, C. E. 801 (2012). Global variations in $\mathrm{H}_{2} \mathrm{O} / \mathrm{Ce}$ : 1 . Slab surface temperatures beneath volcanic 802 arcs. GeocheMItry, Geophysics, Geosystems, 13(3).

803 
804 Danyushevsky, L. V., Sokolov, S., \& Falloon, T. J. (2002). Melt inclusions in olivine 805 phenocrysts: using diffusive re-equilibration to determine the cooling history of a 806 crystal, with implications for the origin of olivine-phyric volcanic rocks. Journal of 807 Petrology, 43(9), 1651-1671.

808

809 Danyushevsky, L. V., \& Plechov, P. (2011). Petrolog3: Integrated software for

810 modeling crystallization processes. GeocheMItry, Geophysics, Geosystems, 12(7).

811

812 Davis, A. S., Clague, D. A., Cousens, B. L., Keaten, R., \& Paduan, J. B. (2008).

813 GeocheMItry of basalt from the North Gorda segment of the Gorda Ridge: Evolution

814 toward ultraslow spreading ridge lavas due to decreasing magma supply.

815 GeocheMItry, Geophysics, Geosystems, 9(4).

816

817 Defant, M. J., \& Drummond, M. S. (1990). Derivation of some modern arc magmas by 818 melting of young subducted lithosphere. Nature, 347(6294), 662-665.

820 Eiler, J. M., Crawford, A., Elliott, T., Farley, K. A., Valley, J. W., \& Stolper, E. M. (2000).

821 Oxygen isotope geocheMItry of oceanic-arc lavas. Journal of Petrology, 41(2), 229822256.

823

824 Eiler, J. M., Carr, M. J., Reagan, M., \& Stolper, E. (2005). Oxygen isotope constraints on 825 the sources of Central American arc lavas. GeocheMItry, Geophysics, Geosystems, 6(7). 826 
827 Ford, C. E., Russell, D. G., Craven, J. A., \& Fisk, M. R. (1983). Olivine-liquid equilibria:

828 temperature, pressure and composition dependence of the crystal/liquid cation

829 partition coefficients for Mg, Fe2+, Ca and Mn. Journal of Petrology, 24(3), 256-266.

830

831 Gerya, T. V., \& Yuen, D. A. (2003). Rayleigh-Taylor instabilities from hydration and

832 melting propel 'cold plumes' at subduction zones. Earth and Planetary Science

833 Letters, 212(1), 47-62.

834

835 Ghiorso, M. S., Hirschmann, M. M., Reiners, P. W., \& Kress, V. C. (2002). The pMELTS:

836 A revision of MELTS for improved calculation of phase relations and major element

837 partitioning related to partial melting of the mantle to $3 \mathrm{GPa}$. GeocheMItry,

838 Geophysics, Geosystems, 3(5), 1-35.

839

840 Grove, T., Parman, S., Bowring, S., Price, R., \& Baker, M. (2002). The role of an $\mathrm{H}_{2} \mathrm{O}$ -

841 rich fluid component in the generation of primitive basaltic andesites and andesites

842 from the Mt. Shasta region, N. California. Contributions to Mineralogy and Petrology,

843 142(4), 375-396.

844

845 Guffanti, M., Clynne, M. A., Smith, J. G., Muffler, L. J. P., \& Bullen, T. D. (1990). Late

846 Cenozoic volcanism, subduction, and extension in the Lassen region of California,

847 southern Cascade Range. Journal of Geophysical Research, 95(B12), 19453-19464.

848 
849 Hermann, J., Spandler, C., Hack, A., \& Korsakov, A. V. (2006). Aqueous fluids and 850 hydrous melts in high-pressure and ultra-high pressure rocks: implications for

851 element transfer in subduction zones. Lithos, 92(3), 399-417.

852

853 Hirschmann, M. M., Baker, M. B., \& Stolper, E. M. (1998). The effect of alkalis on the

854 silica content of mantle-derived melts. Geochimica et Cosmochimica Acta, 62(5), 883-

855902.

856

857 Irwin, W.P., \& Wooden, J.L., 1999, Plutons and accretionary episodes of the Klamath

858 Mountains, California and Oregon. U. S. Geological Survey, Open-file Report 99-374.

859

860 Ishikawa, T., \& Nakamura, E. (1993). Boron isotope systematics of marine sediments.

861 Earth and Planetary Science Letters, 117(3), 567-580.

862

863 Ishikawa, T., \& Tera, F. (1999). Two isotopically distinct fluid components involved

864 in the Mariana arc: Evidence from $\mathrm{Nb} / \mathrm{B}$ ratios and $\mathrm{B}, \mathrm{Sr}, \mathrm{Nd}$, and $\mathrm{Pb}$ isotope

865 systematics. Geology, 27(1), 83-86.

866

867 Ishikawa, T., \& Tera, F. (1999). Two isotopically distinct fluid components involved

868 in the Mariana Arc: Evidence from $\mathrm{Nb} / \mathrm{B}$ ratios and $\mathrm{B}, \mathrm{Sr}, \mathrm{Nd}$, and $\mathrm{Pb}$ isotope

869 systematics. Geology, 27(1), 83-86.

870 
871 Ishikawa, T., Tera, F., \& Nakazawa, T. (2001). Boron isotope and trace element

872 systematics of the three volcanic zones in the Kamchatka arc. Geochimica et

873 Cosmochimica Acta, 65(24), 4523-4537.

874

875 Jicha, B. R., Hart, G. L., Johnson, C. M., Hildreth, W., Beard, B. L., Shirey, S. B., \& Valley, J.

876 W. (2009). Isotopic and trace element constraints on the petrogenesis of lavas from

877 the Mount Adams volcanic field, Washington. Contributions to Mineralogy and

878 Petrology, 157(2), 189-207.

879

880 Johnson, E. R., Wallace, P. J., Cashman, K. V., Granados, H. D., \& Kent, A. J. (2008).

881 Magmatic volatile contents and degassing-induced crystallization at Volcán Jorullo,

882 Mexico: implications for melt evolution and the plumbing systems of monogenetic

883 volcanoes. Earth and Planetary Science Letters, 269(3), 478-487.

884

885 Johnson, E. R., Wallace, P. J., Granados, H. D., Manea, V. C., Kent, A. J., Bindeman, I. N.,

886 \& Donegan, C. S. (2009). Subduction-related volatile recycling and magma

887 generation beneath Central Mexico: insights from melt inclusions, oxygen isotopes

888 and geodynamic models. Journal of Petrology, 50(9), 1729-1764.

889

890 Kelemen, P. B., Shimizu, N., \& Dunn, T. (1993). Relative depletion of niobium in some

891 arc magmas and the continental crust: partitioning of $\mathrm{K}, \mathrm{Nb}$, La and Ce during

892 melt/rock reaction in the upper mantle. Earth and Planetary Science Letters, 120(3),

893 111-134. 
895 Kelemen, P. B., Yogodzinski, G. M., \& Scholl, D. W. (2003). Along-strike variation in

896 the Aleutian island arc: Genesis of high Mg\# andesite and implications for

897 continental crust. Inside the Subduction Factory, Geophys. Monogr. Ser, 138, 223-276.

898

899 Kessel, R., Schmidt, M. W., Ulmer, P., \& Pettke, T. (2005). Trace element signature of

900 subduction-zone fluids, melts and supercritical liquids at 120-180 km depth. Nature, $901 \quad 437(7059), 724-727$.

902

903 Kimura, J. I., \& Nakajima, J. (2014). Behaviour of subducted water and its role in

904 magma genesis in the NE Japan arc: A combined geophysical and geochemical

905 approach. Geochimica et Cosmochimica Acta, 143, 165-188.

906

907 Klimm, K., Blundy, J. D., \& Green, T. H. (2008). Trace element partitioning and

908 accessory phase saturation during H2O-saturated melting of basalt with

909 implications for subduction zone chemical fluxes. Journal of Petrology, 49(3), 523-

910553.

911

912 Krawczynski, M. J., Grove, T. L., \& Behrens, H. (2012). Amphibole stability in

913 primitive arc magmas: effects of temperature, $\mathrm{H}_{2} \mathrm{O}$ content, and oxygen fugacity.

914 Contributions to Mineralogy and Petrology, 164(2), 317-339.

915 
916 Leeman, W. P., Tonarini, S., Chan, L. H., \& Borg, L. E. (2004). Boron and lithium

917 isotopic variations in a hot subduction zone-the southern Washington Cascades.

918 Chemical Geology, 212(1), 101-124.

919

920 Liu, K., Levander, A., Zhai, Y., Porritt, R. W., \& Allen, R. M. (2012). Asthenospheric

921 flow and lithospheric evolution near the Mendocino Triple Junction. Earth and

922 Planetary Science Letters, 323, 60-71.

923

924 Lloyd, A. S., Plank, T., Ruprecht, P., Hauri, E. H., \& Rose, W. (2013). Volatile loss from

925 melt inclusions in pyroclasts of differing sizes. Contributions to Mineralogy and

926 Petrology, 165(1), 129-153.

927

928 Loewen, M. W., \& Kent, A. J. (2012). Sources of elemental fractionation and

929 uncertainty during the analysis of semi-volatile metals in silicate glasses using LA-

930 ICP-MS. Journal of Analytical Atomic Spectrometry, 27(9), 1502-1508.

931

932 Le Voyer, M., Rose-Koga, E. F., Shimizu, N., Grove, T. L., \& Schiano, P. (2010). Two

933 contrasting $\mathrm{H}_{2} \mathrm{O}$-rich components in primary melt inclusions from Mount Shasta.

934 Journal of Petrology, 51(7), 1571-1595.

935

936 Mallik, A., Nelson, J., \& Dasgupta, R. (2015). Partial melting of fertile peridotite fluxed

937 by hydrous rhyolitic melt at 2-3 GPa: implications for mantle wedge hybridization 
938 by sediment melt and generation of ultrapotassic magmas in convergent margins.

939 Contributions to Mineralogy and Petrology, 169(5), 1-24.

940

941 Manea, V. C., Leeman, W. P., Gerya, T., Manea, M., \& Zhu, G. (2014). Subduction of

942 fracture zones controls mantle melting and geochemical signature above slabs.

943 Nature Communications, 5.

944

945 Marschall, H. R., \& Monteleone, B. D. (2014). Boron isotope analysis of silicate glass

946 with very low boron concentrations by Secondary Ion Mass Spectrometry.

947 Geostandards and Geoanalytical Research. 39(1), 31-46.

948

949 Marschall, H. R., Altherr, R., \& Rüpke, L. (2007). Squeezing out the slab-modelling

950 the release of $\mathrm{Li}, \mathrm{Be}$ and $\mathrm{B}$ during progressive high-pressure metamorphism.

951 Chemical Geology, 239(3), 323-335.

952

953 Moore, L. R., Gazel, E., Tuohy, R., Lloyd, A. S., Esposito, R., Steele-MacInnis, M., \&

954 Bodnar, R. J. (2015). Bubbles matter: An assessment of the contribution of vapor

955 bubbles to melt inclusion volatile budgets. American Mineralogist, 100(4), 806-823.

956

957 Mullen, E. K., \& Weis, D. (2015). Evidence for trench-parallel mantle flow in the

958 northern Cascade Arc from basalt geocheMItry. Earth and Planetary Science Letters, $959414,100-107$.

960 
961 Nedimović, M. R., Bohnenstiehl, D. R., Carbotte, S. M., Canales, J. P., \& Dziak, R. P.

962 (2009). Faulting and hydration of the Juan de Fuca plate system. Earth and Planetary

963 Science Letters, 284(1), 94-102.

964

965 Mallmann, G., \& O’Neill, H. S. C. (2009). The crystal/melt partitioning of V during

966 mantle melting as a function of oxygen fugacity compared with some other elements

967 (Al, P, Ca, Sc, Ti, Cr, Fe, Ga, Y, Zr and Nb). Journal of Petrology, 50(9), 1765-1794.

968

969 Plank, T. (2005). Constraints from thorium/lanthanum on sediment recycling at

970 subduction zones and the evolution of the continents. Journal of Petrology, 46(5),

$971921-944$.

972

973 Plank, T., Kelley, K. A., Zimmer, M. M., Hauri, E. H., \& Wallace, P. J. (2013). Why do

974 mafic arc magmas contain $4 \mathrm{wt} \%$ water on average? Earth and Planetary Science

975 Letters, 364, 168-179.

976

977 Portnyagin, M., Hoernle, K., Plechov, P., Mironov, N., \& Khubunaya, S. (2007).

978 Constraints on mantle melting and composition and nature of slab components in

979 volcanic arcs from volatiles $\left(\mathrm{H}_{2} \mathrm{O}, \mathrm{S}, \mathrm{Cl}, \mathrm{F}\right)$ and trace elements in melt inclusions from

980 the Kamchatka Arc. Earth and Planetary Science Letters, 255(1), 53-69. 
982 Ranero, C. R., Morgan, J. P., McIntosh, K., \& Reichert, C. (2003). Bending-related

983 faulting and mantle serpentinization at the Middle America trench. Nature,

$984 \quad 425(6956), 367-373$.

985

986 Rose, E. F., Shimizu, N., Layne, G. D., \& Grove, T. L. (2001). Melt production beneath

987 Mt. Shasta from boron data in primitive melt inclusions. Science, 293(5528), 281-

988283.

989

990 Ruscitto, D. M., Wallace, P. J., Johnson, E. R., Kent, A. J. R., \& Bindeman, I. N. (2010).

991 Volatile contents of mafic magmas from cinder cones in the Central Oregon High

992 Cascades: 63. Implications for magma formation and mantle conditions in a hot arc.

993 Earth and Planetary Science Letters, 298(1), 153-161.

994

995 Ruscitto, D. M., Wallace, P. J., \& Kent, A. J. R. (2011). Revisiting the compositions and

996 volatile contents of olivine-hosted melt inclusions from the Mount Shasta region:

997 implications for the formation of high-Mg andesites. Contributions to Mineralogy and

998 Petrology, 162(1), 109-132.

999

1000 Ruscitto, D. M., Wallace, P. J., Cooper, L. B., \& Plank, T. (2012). Global variations in

1001 H2O/Ce: 2. Relationships to arc magma geocheMItry and volatile fluxes.

1002 GeocheMItry, Geophysics, Geosystems, 13(3).

1003 
1004 Schmidt, M. W., \& Poli, S. (1998). Experimentally based water budgets for

1005 dehydrating slabs and consequences for arc magma generation. Earth and Planetary

1006 Science Letters, 163(1), 361-379.

1007

1008 Spandler, C., \& Pirard, C. (2013). Element recycling from subducting slabs to arc

1009 crust: a review. Lithos, 170, 208-223.

1010

1011 Spandler, C., Pettke, T., \& Hermann, J. (2014). Experimental study of trace element

1012 release during ultrahigh-pressure serpentinite dehydration. Earth and Planetary

1013 Science Letters, 391, 296-306.

1014

1015 Sun, S. S., \& McDonough, W. F. (1989). Chemical and isotopic systematics of oceanic

1016 basalts: implications for mantle composition and processes. Geological Society,

1017 London, Special Publications, 42(1), 313-345.

1018

1019 Syracuse, E. M., van Keken, P. E., \& Abers, G. A. (2010). The global range of

1020 subduction zone thermal models. Physics of the Earth and Planetary Interiors, 183(1),

$102173-90$.

1022

1023 Till, C. B., Grove, T. L., Carlson, R. W., Donnelly-Nolan, J. M., Fouch, M. J., Wagner, L. S.,

$1024 \&$ Hart, W. K. (2013). Depths and temperatures of $<10.5$ Ma mantle melting and the

1025 lithosphere-asthenosphere boundary below southern Oregon and northern

1026 California. GeocheMItry, Geophysics, Geosystems, 14(4), 864-879. 
1028 Tonarini, S., Armienti, P., D’Orazio, M., \& Innocenti, F. (2001). Subduction-like fluids

1029 in the genesis of Mt. Etna magmas: evidence from boron isotopes and fluid mobile 1030 elements. Earth and Planetary Science Letters, 192(4), 471-483.

1031

1032 Turner, S. J., \& C. H. Langmuir (2015). What processes control the chemical

1033 compositions of arc front stratovolcanoes? GeocheMItry, Geophysics, Geosystems. 16, $1034 \quad 1865-1893$

1035

1036 Van Keken, P. E., Hacker, B. R., Syracuse, E. M., \& Abers, G. A. (2011). Subduction

1037 factory: 4. Depth-dependent flux of $\mathrm{H}_{2} \mathrm{O}$ from subducting slabs worldwide. Journal of 1038 Geophysical Research: Solid Earth (1978-2012), 116(B1).

1039

1040 Wada, I., \& Wang, K. (2009). Common depth of slab-mantle decoupling: Reconciling

1041 diversity and uniformity of subduction zones. GeocheMItry, Geophysics, Geosystems, 1042 10(10).

1043

1044 Wallace, P. J., Kamenetsky, V. S., \& Cervantes, P. (2015). Melt inclusion $\mathrm{CO}_{2}$ contents, 1045 pressures of olivine crystallization, and the problem of shrinkage bubbles. American 1046 Mineralogist, 100(4), 787-794. 
1048 Walowski, K.J., Wallace P.J., Hauri, E.K., Wada, I., Clynne, M. A., (2015) Slab melting

1049 beneath the Cascade Arc driven by dehydration of altered oceanic peridotite. Nature

1050 Geoscience, 8(5), 404-408.

1051

1052 Wannamaker, P. E., Booker, J. R., Jones, A. G., Chave, A. D., Filloux, J. H., Waff, H. S., \&

1053 Law, L. K. (1989). Resistivity cross section through the Juan de Fuca subduction

1054 system and its tectonic implications. Journal of Geophysical Research: Solid Earth

1055 (1978-2012), 94(B10), 14127-14144.

1056

1057

1058 Weis, D., Kieffer, B., Maerschalk, C., Barling, J., De Jong, J., Williams, G. A, \& Mahoney, J.

1059 B. (2006). High-precision isotopic characterization of USGS reference materials by

1060 TIMS and MC-ICP-MS. GeocheMItry, Geophysics, Geosystems, 7(8).

1061

1062 Weis, D., Kieffer, B., Hanano, D., Nobre Silva, I., Barling, J., Pretorius, W. \& Mattielli, N.

1063 (2007). Hf isotope compositions of US Geological Survey reference materials.

1064 GeocheMItry, Geophysics, Geosystems, 8(6).

1065

1066 Wilson, D. S. (2002). The Juan de Fuca plate and slab: Isochron structure and

1067 Cenozoic plate motions. US Geological Survey Open-File Report, 02-328.

1068

1069 Workman, R. K., \& Hart, S. R. (2005). Major and trace element composition of the

1070 depleted MORB mantle (DMM). Earth and Planetary Science Letters, 231(1), 53-72. 

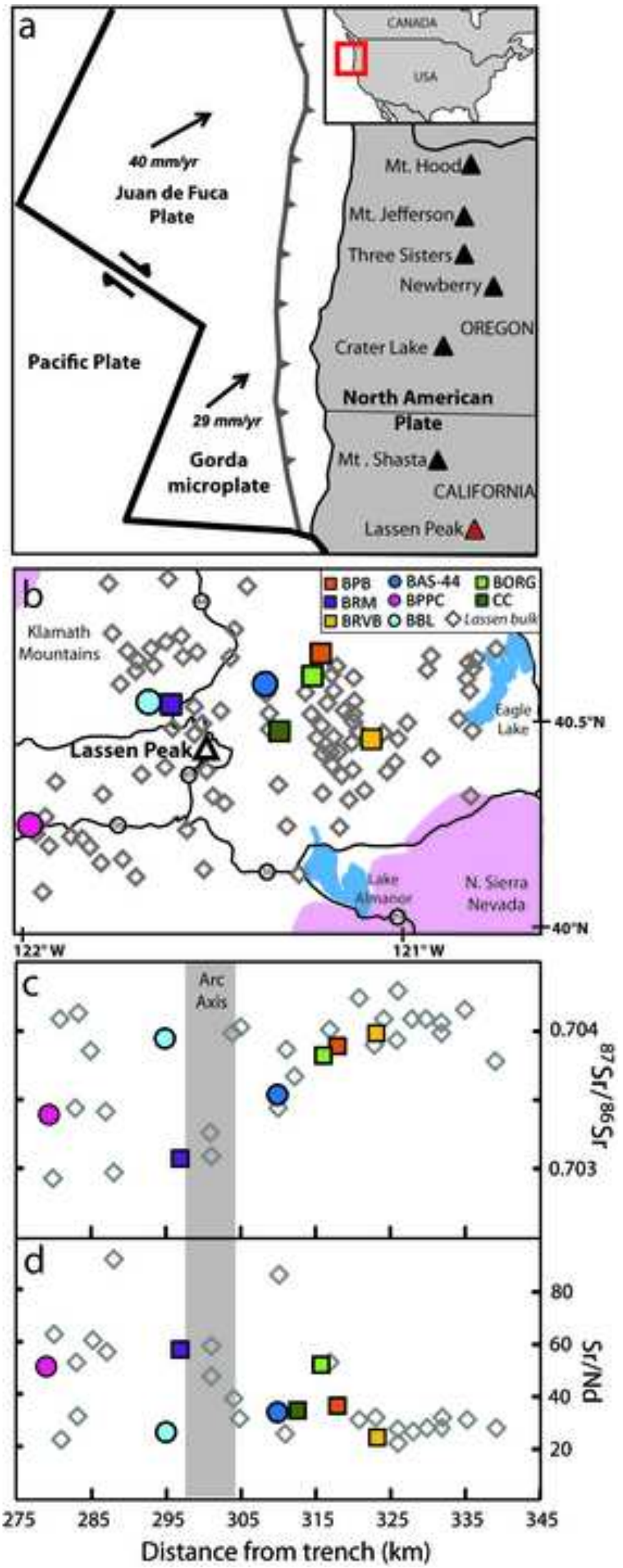

FIGURE 1 

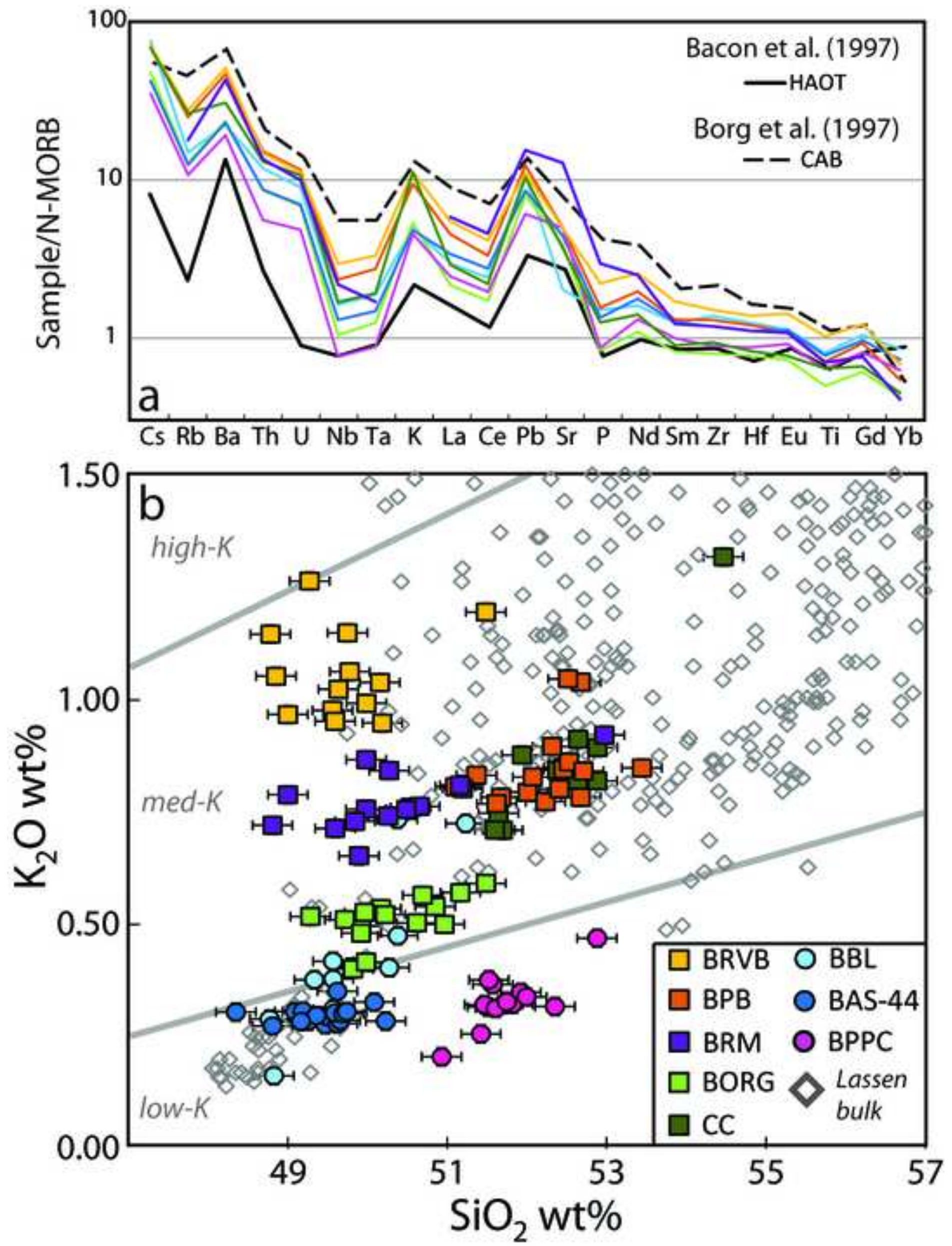

FIGURE 2 


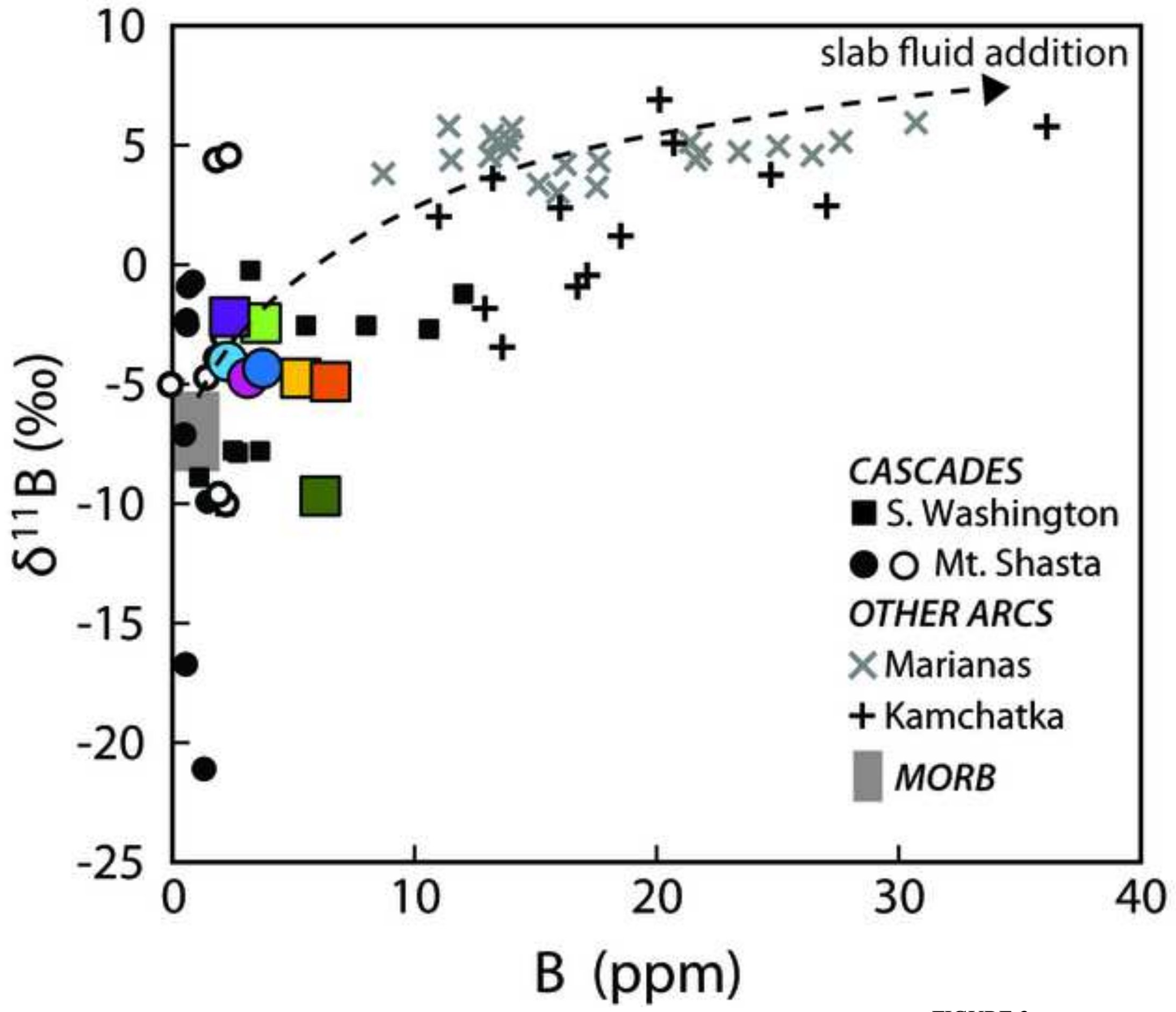



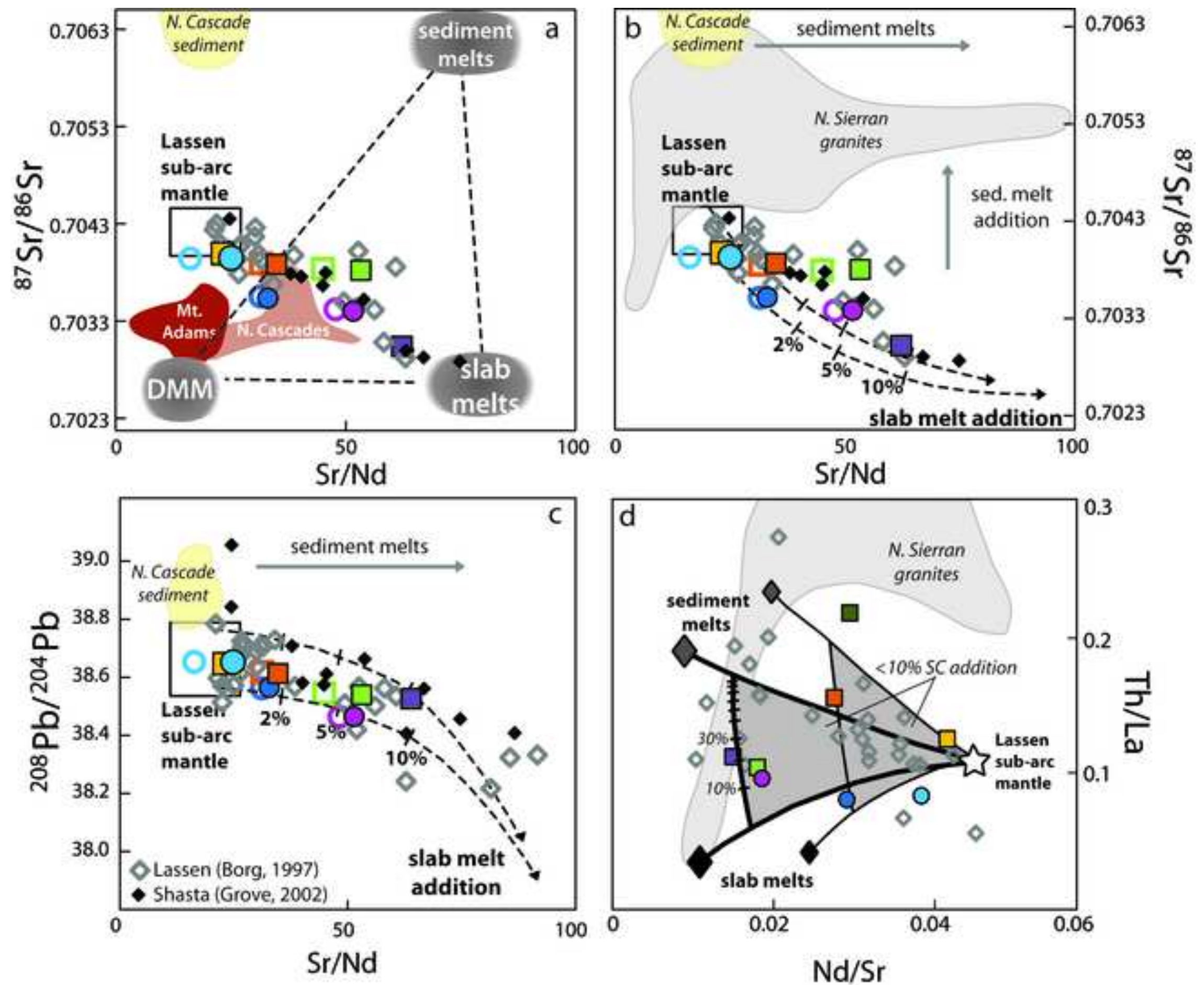

FIGURE 4 



FIGURE 5 

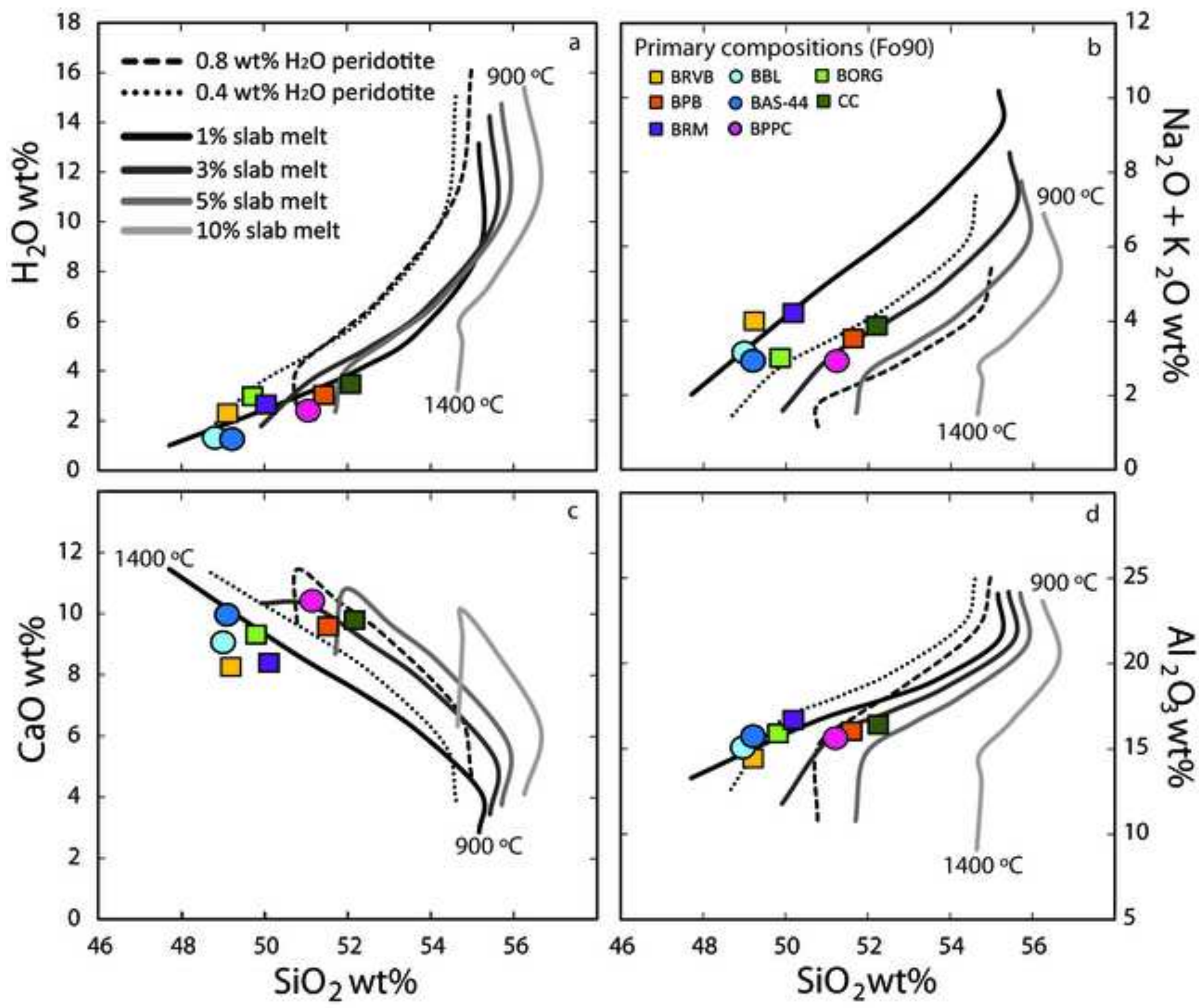

FIGURE 6 


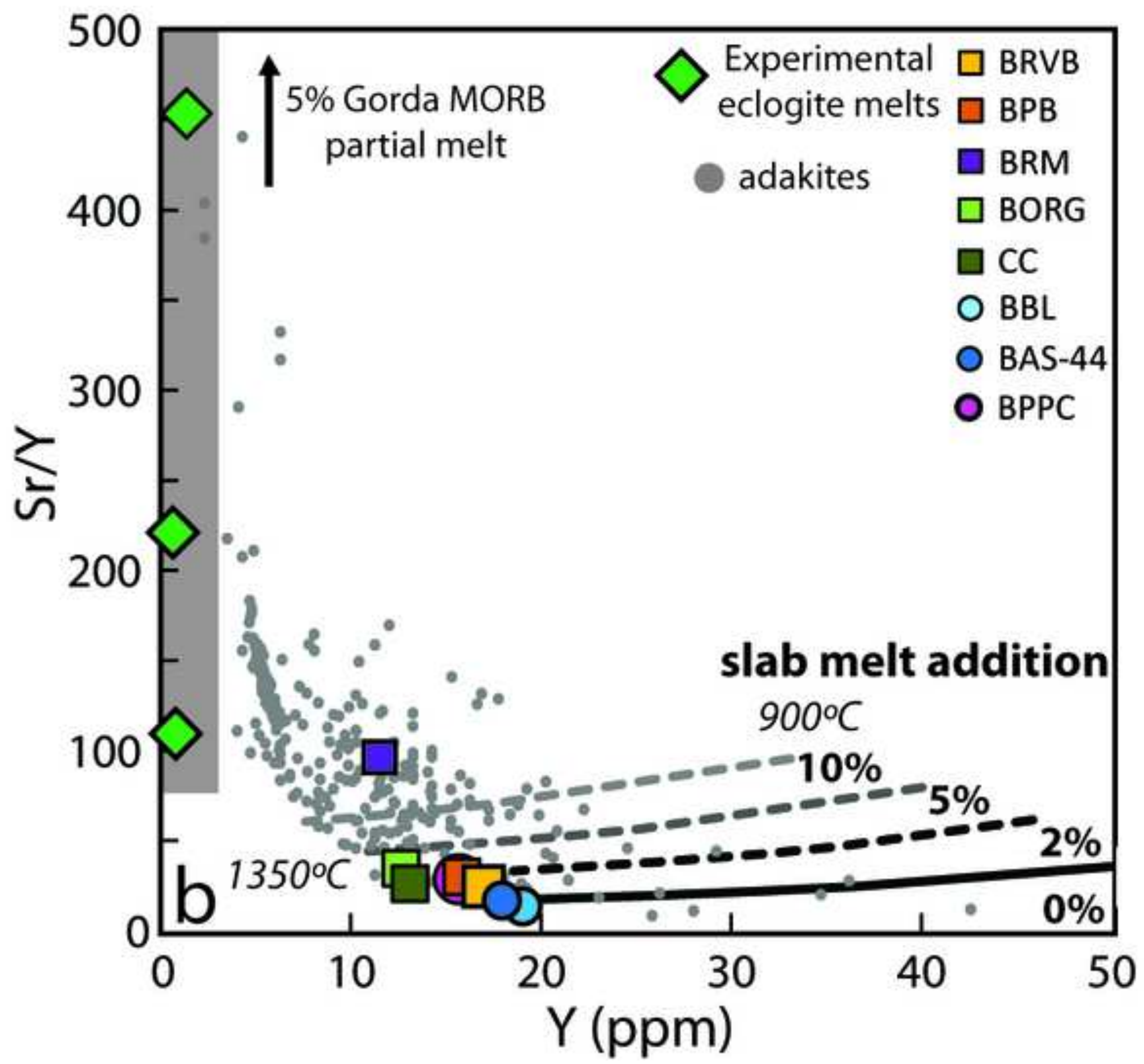




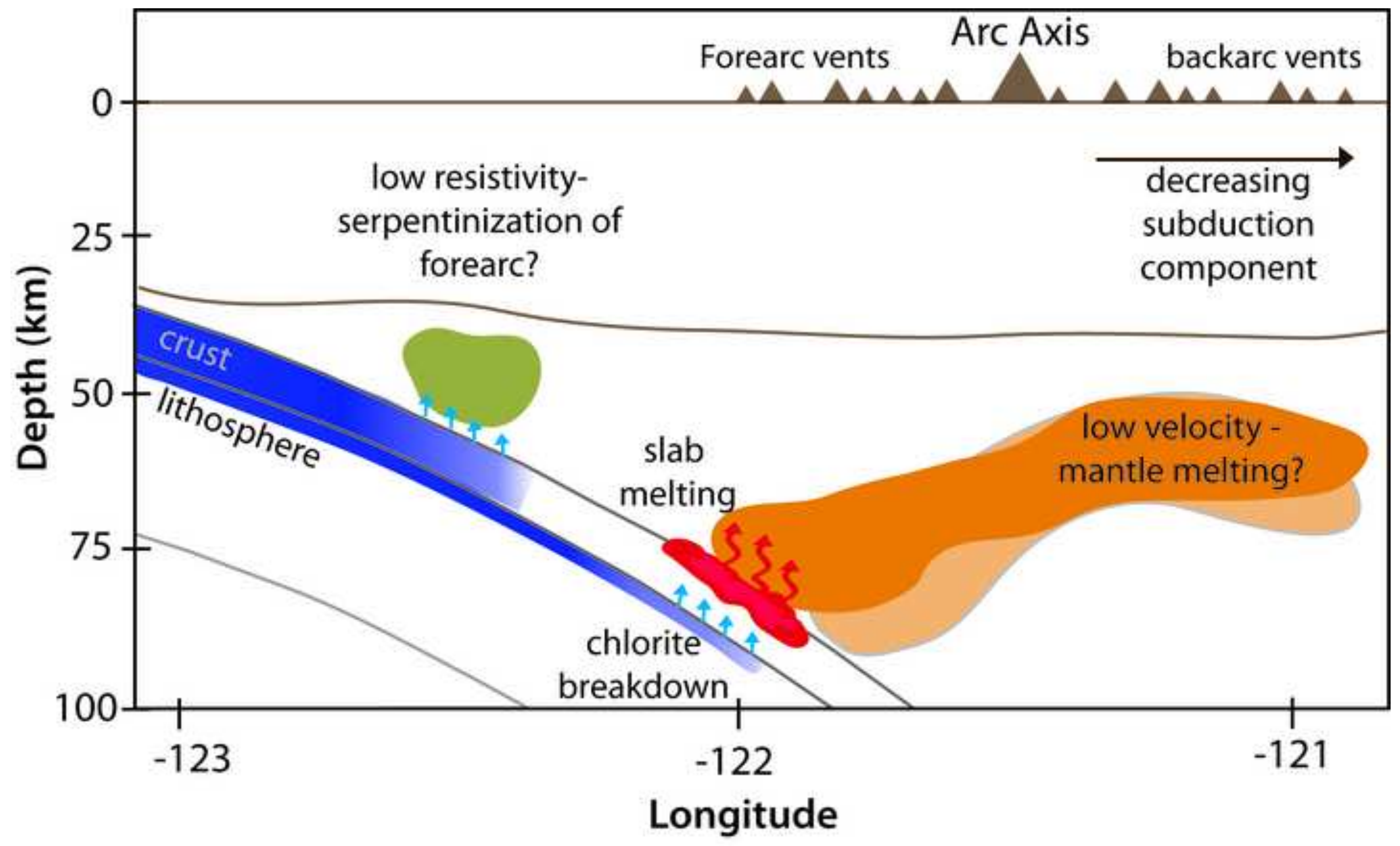


Table 1: Primary melt compositions (Major and Volatile)

\begin{tabular}{|c|c|c|c|c|c|c|c|c|}
\hline Sample & BBL-05 & BORG-1 & BPB-1 & BAS-44-02 & BPPC-01 & BRVB-01 & CC-1 & BRM-1 \\
\hline Lat $(\mathrm{N})$ & $40^{\circ} 34^{\prime} 33.72^{\prime \prime}$ & $40^{\circ} 39^{\prime} 15.63^{\prime \prime}$ & $40^{\circ} 40^{\prime} 40.80^{\prime \prime}$ & $40^{\circ} 37^{\prime} 50.64^{\prime \prime}$ & $40^{\circ} 19^{\prime} 34.22^{\prime \prime}$ & $40^{\circ} 31^{\prime} 48.78^{\prime \prime}$ & $40^{\circ} 32^{\prime} 24.50^{\prime \prime}$ & $40^{\circ} 34^{\prime} 13.17^{\prime \prime}$ \\
\hline Long (W) & $121^{\circ} 37^{\prime} 1.32^{\prime \prime}$ & $121^{\circ} 13^{\prime 2} 29.07^{\prime \prime}$ & $121^{\circ} 12^{\prime} 51.00^{\prime \prime}$ & $121^{\circ} 20^{\prime} 40.14^{\prime \prime}$ & $121^{\circ} 54^{\prime} 38.64 "$ & $121^{\circ} 4^{\prime} 34.32^{\prime \prime}$ & $121^{\circ} 18^{\prime} 37.00^{\prime \prime}$ & $121^{\circ} 35^{\prime} 31.59^{\prime \prime}$ \\
\hline${ }^{\mathrm{a}}$ Distance (km) & $\mathrm{n}=11 \quad l s . d$. & $\mathrm{n}=15$ & $\mathrm{n}=16$ & $\mathrm{n}=17$ & $\mathrm{n}=14$ & $\mathrm{n}=14$ & $\mathrm{n}=13$ & $\mathrm{n}=15$ \\
\hline $\mathrm{SiO}_{2}(w t \%)$ & $48.94 \quad 0.22$ & 49.950 .14 & 51.520 .26 & 49.420 .33 & 51.160 .12 & 48.960 .20 & 52.540 .15 & 49.850 .11 \\
\hline $\mathrm{TiO}_{2}$ & 0.920 .04 & 0.700 .01 & 0.840 .01 & 0.930 .07 & 0.760 .02 & 1.220 .01 & $0.86 \quad 0.02$ & 0.770 .00 \\
\hline $\mathbf{A l}_{2} \mathbf{O}_{3}$ & 14.720 .15 & 16.140 .16 & 15.980 .33 & 16.230 .29 & 15.690 .11 & $13.98 \quad 0.12$ & 17.150 .25 & 16.250 .11 \\
\hline${ }^{\mathrm{b}} \mathrm{FeO}^{\mathrm{T}}$ & 9.10 & 8.18 & 7.23 & 8.22 & 7.38 & 9.24 & 5.93 & 8.06 \\
\hline MnO & 0.120 .007 & 0.100 .005 & 0.110 .005 & 0.120 .002 & 0.120 .005 & 0.110 .002 & 0.090 .004 & 0.090 .002 \\
\hline MgO & $14.01 \quad 0.28$ & $12.40 \quad 0.13$ & $11.00 \quad 0.27$ & 11.500 .09 & 11.180 .07 & 14.300 .09 & 8.850 .27 & 12.410 .07 \\
\hline $\mathrm{CaO}$ & 8.820 .15 & 9.330 .05 & 9.530 .18 & 10.280 .14 & 10.510 .07 & 7.960 .17 & 10.310 .18 & 8.120 .04 \\
\hline $\mathrm{Na}_{2} \mathrm{O}$ & 2.720 .08 & 2.500 .04 & 2.670 .07 & 2.680 .06 & 2.600 .04 & 2.910 .06 & 3.150 .07 & 3.400 .08 \\
\hline $\mathbf{K}_{2} \mathbf{O}$ & 0.360 .016 & 0.470 .003 & 0.780 .007 & 0.280 .016 & 0.300 .004 & $0.93 \quad 0.002$ & 0.850 .004 & 0.680 .002 \\
\hline $\mathbf{S}$ & 0.090 .003 & 0.110 .004 & 0.090 .010 & 0.110 .016 & 0.110 .004 & 0.130 .003 & 0.090 .007 & 0.160 .002 \\
\hline Cl & 0.020 .002 & 0.050 .001 & 0.050 .005 & $0.03 \quad 0.002$ & 0.040 .001 & 0.040 .000 & 0.040 .002 & 0.200 .001 \\
\hline${ }^{\mathrm{c}} \mathrm{CO}_{2}(\mathrm{ppm})$ & 88452 & 1384111 & 143647 & 75456 & 120972 & 622118 & 143658 & 52144 \\
\hline${ }^{\mathrm{d}} \mathrm{H}_{2} \mathrm{O}(w t \%)$ & 1.290 .08 & 3.020 .15 & 2.940 .22 & 1.210 .22 & 2.290 .14 & 2.280 .10 & 3.450 .10 & 2.580 .03 \\
\hline${ }^{\mathrm{e}} \% \mathrm{OI}$ & 17.0 & 7.9 & 8.8 & 4.0 & 7.5 & 20.1 & 1.0 & 14.8 \\
\hline
\end{tabular}

Primary melt compositions refer to the average MI composition calculated to be in equilibrium with $\mathrm{Fo}_{90}$ olivine for each cone (further explanation in Methods).

Major element uncertainty calculated as one standard deviation of the population used to calculate the average MI composition from each cone (including analytical uncertainty)

The complete corrected and uncorrected dataset of MI compositions can be found in Supplementary Tables S1 and S4. Sample names are abbreviations based on Clynne and Muffler (2010): $\mathrm{BBL}=$ Basalt of Big Lake; BORG = Basalt of Old Railroad Grade 3; BPB = Basalt of Poison Butte 3; BAS-44 = Basalt of Highway 44; and unpublished locations:

BPPC = Basalt of Paynes Creek Parasitic Cone; BRVB = Basalt of Round Valley Butte; BRM = Basalt of Red Mountain. Locations are based on NAD27 datum used in Clynne and Muffler (2010). Major and trace element compositions of bulk tephra can be found in Walowski et al. (2015). Additional data can be found in Clynne et al. (2008); Borg et al. (1997, 2002, 2000); Clynne (1993) ${ }^{a}$ Distance refers to estimated distance from the offshore trench in kilometers

${ }^{\mathrm{b}}$ Initial $\mathrm{Fe}$ contents used in the calculations were chosen based either on the $\mathrm{FeO}^{\mathrm{T}}$ of the bulk tephra or the highest value of $\mathrm{FeO}^{\mathrm{T}}$ for $\mathrm{MI}$ from a particular cone

${ }^{\mathrm{c}} \mathrm{CO}_{2}$ values represent the highest from each cone after PEC correction and recalculation for melt in equilibrium with $\mathrm{Fo}_{90}$ olivine

${ }^{\mathrm{d}} \mathrm{H}_{2} \mathrm{O}$ values represent the highest from each cone after PEC correction and recalculation for melt in equilibrium with $\mathrm{Fo}_{90}$ olivine

${ }^{\mathrm{e}}$ Refers to the percent olivine required for equilibrium with $\mathrm{Fo}_{90}$ olivine 
Table 2: Primary Melt Compositions (Trace Element and Isotopic)

\begin{tabular}{|c|c|c|c|c|c|c|c|c|c|}
\hline Sample & BBL-05 & 1 s.d. & BORG-1 & BPB-1 & BAS-44-02 & BPPC-01 & BRVB-01 & CC-1 & BRM-1 \\
\hline$\overline{\mathbf{L i}}$ & 7.2 & 0.4 & 7.00 .8 & 7.40 .8 & 5.41 .2 & 6.20 .3 & 11.51 .8 & 10.40 .4 & 7.30 .6 \\
\hline B & 1.8 & 0.4 & 3.71 .0 & 8.30 .2 & $2.6 \quad 10.1$ & 3.00 .3 & 8.00 .6 & 5.30 .3 & 3.20 .3 \\
\hline Sc & 38 & 1.1 & 381.5 & 340.7 & 411.8 & 350.7 & 320.7 & 271.1 & 231.4 \\
\hline $\mathbf{V}$ & 225 & & 2779 & 2057 & 21816 & 2102 & 2524 & 18610 & 1935 \\
\hline $\mathbf{R b}$ & 5.49 & 0.67 & 5.440 .64 & 14.240 .54 & $4.79 \quad 1.29$ & 5.070 .30 & 21.561 .46 & 15.390 .37 & $10.43 \quad 0.20$ \\
\hline $\mathrm{Sr}$ & 270 & 10 & 4388 & 47641 & 40812 & 45011 & 4545 & 34225 & 11976 \\
\hline $\mathbf{Y}$ & 21.2 & 0.7 & 12.60 .4 & 15.80 .2 & 18.61 .5 & 15.70 .4 & 18.30 .3 & 13.10 .4 & 11.40 .2 \\
\hline $\mathbf{Z r}$ & 79 & 6 & 522 & 932 & 789 & 592 & 1052 & 712 & 901 \\
\hline Nb & 3.0 & 0.4 & 2.10 .1 & 5.60 .3 & 2.70 .5 & 1.40 .1 & 7.00 .1 & 4.00 .1 & 5.20 .1 \\
\hline $\mathbf{B a}$ & 157 & 20 & 1419 & 2968 & 11718 & 1095 & 37810 & 20312 & 2775 \\
\hline La & 6.2 & 0.8 & 5.60 .3 & 11.30 .3 & 7.40 .9 & 5.60 .2 & $\begin{array}{lll}14.2 & 0.2\end{array}$ & 7.50 .3 & 15.00 .1 \\
\hline $\mathrm{Ce}$ & 15.9 & 1.8 & 12.81 .0 & 24.00 .7 & 19.61 .8 & 13.00 .5 & 34.90 .3 & 16.90 .6 & 35.50 .3 \\
\hline Pr & 2.20 & 0.24 & 1.700 .10 & 3.300 .06 & 2.680 .30 & 1.800 .06 & 4.370 .05 & 2.310 .08 & 4.360 .02 \\
\hline Nd & 10.80 & 0.94 & 8.250 .54 & 13.670 .33 & 12.381 .42 & 8.730 .26 & 19.660 .48 & 10.520 .36 & 18.770 .14 \\
\hline Sm & 2.77 & 0.18 & 2.240 .14 & 3.120 .09 & 2.910 .28 & 2.230 .14 & 4.250 .05 & 2.410 .08 & 3.300 .06 \\
\hline $\mathbf{E u}$ & 1.04 & 0.05 & 0.840 .02 & 1.050 .03 & 1.010 .06 & 0.850 .03 & 1.350 .04 & 0.800 .03 & 1.120 .02 \\
\hline Gd & 3.50 & 0.15 & 2.430 .15 & 3.130 .05 & 3.190 .29 & 2.770 .14 & 3.960 .08 & 2.470 .11 & 2.860 .03 \\
\hline Dy & 3.80 & 0.12 & 2.430 .09 & 2.880 .08 & 3.010 .23 & 2.670 .07 & 3.660 .06 & 2.550 .10 & 2.110 .23 \\
\hline $\mathbf{E r}$ & 2.51 & 0.09 & $1.40 \quad 0.12$ & 1.800 .07 & 2.210 .15 & 1.810 .09 & 1.970 .11 & 1.390 .06 & 1.240 .03 \\
\hline $\mathbf{Y b}$ & 2.47 & 0.08 & 1.370 .08 & 1.730 .08 & 2.110 .16 & 1.730 .04 & 1.920 .05 & 1.390 .06 & 1.270 .04 \\
\hline Hf & 1.78 & 0.14 & 1.350 .15 & 2.220 .09 & 1.990 .18 & 1.710 .07 & 2.540 .17 & 1.730 .05 & 2.330 .03 \\
\hline Ta & 0.17 & 0.03 & 0.110 .02 & 0.340 .01 & 0.150 .03 & $0.08 \quad 0.01$ & 0.350 .02 & 0.260 .01 & 0.230 .00 \\
\hline $\mathbf{P b}$ & 1.85 & 0.25 & 2.260 .20 & 4.010 .14 & 1.540 .28 & 1.620 .10 & 4.140 .41 & 3.220 .21 & 4.810 .06 \\
\hline Th & 0.52 & 0.07 & 0.580 .10 & 1.750 .06 & 0.590 .09 & 0.540 .03 & 1.770 .09 & 1.630 .06 & 1.680 .01 \\
\hline $\mathbf{U}$ & 0.18 & 0.03 & 0.290 .02 & 0.490 .02 & 0.210 .04 & $0.18 \quad 0.02$ & 0.610 .04 & $0.52 \quad 0.03$ & 0.490 .01 \\
\hline${ }^{\overline{f 87}} \mathrm{Sr} /{ }^{86} \mathrm{Sr}$ & 0.703939 & & 0.703813 & 0.703877 & 0.703529 & 0.703396 & 0.703985 & $\mathrm{~N} / \mathrm{A}$ & 0.703080 \\
\hline${ }^{f 208} \mathrm{~Pb} /{ }^{204} \mathrm{~Pb}$ & 38.650 & & 38.539 & 38.612 & 38.564 & 38.464 & 38.646 & N/A & 38.562 \\
\hline${ }^{f 177} \mathbf{H f} /{ }^{176} \mathrm{Hf}$ & 0.283057 & & 0.283055 & 0.283059 & 0.283094 & 0.283052 & 0.283035 & $\mathrm{~N} / \mathrm{A}$ & N/A \\
\hline${ }^{f 143} \mathrm{Nd} /{ }^{144} \mathrm{Nd}$ & 0.512859 & & 0.512864 & 0.512827 & 0.512948 & 0.512926 & 0.512833 & $\mathrm{~N} / \mathrm{A}$ & 0.512901 \\
\hline${ }^{\mathrm{g}} \delta^{11} \mathrm{~B} \%$ o ( $\left.\pm 1 \mathrm{SE}\right)$ & $-4.2(0.9)$ & & $-2.6(1.0)$ & $-5.0(0.8)$ & $-4.5(0.8)$ & $-4.9(0.3)$ & $-5.0(0.2)$ & $-10.0(1.0)$ & $-2.4(0.7)$ \\
\hline${ }^{\mathrm{e}} \boldsymbol{\delta} \mathrm{D}_{\text {initial }} \%$ & -85 & & -90 & -80 & -70 & -75 & -75 & -95 & N/A \\
\hline
\end{tabular}

Primary melt trace element compositions refer to the average MI composition calculated to be in equilibrium with $\mathrm{Fo}_{90}$ olivine for each cone.

Trace element uncertainty calculated as 1 standard deviation of the population used to calculate the average MI composition from each cone (including analytical uncertainty)

Sample names are abbreviations based on Clynne and Muffler (2010), as described in Table 1. Radiogenic isotope analyses are bulk tephra analyses as described discussion section 3

${ }^{1}$ Errors for individual radiogenic isotope compositions can be found in Supplementary Table S2

${ }^{\mathrm{e}} \delta^{11} \mathrm{~B}$ values represent an average from 4-8 MI from an individual vent. See Supplementary Table S3 for details.

${ }^{\mathrm{g}} \delta \mathrm{D}$ values from Walowski et al. (2015), measured on the same MI that were analyzed for $\delta^{11} \mathrm{~B}$ 